\title{
Pharmacological activities of pyridazines and pyridazinone Derivatives: A Review on biologically active scaffold
}

\author{
${ }^{*}$ Corresponding Author \\ Mohammad Asif \\ Article History \\ Received: 10.07.2019 \\ Accepted: 22.07.2019 \\ Published: 30.07 .2019
}

Abida1 ${ }^{1}$ Md. Tauquir Alam¹, Mohammad Asif2*

${ }^{1}$ Department of Pharmaceutical Chemistry, Faculty of Pharmacy, Northern Border University, Rafha 91911, P0 Box 840, Saudi Arabia

2Department of Pharmaceutical chemistry, Himaayan Institute of Pharmacy \& Research, Dehradun, (UK), 248007, India

\begin{abstract}
Pyridazine and pyridazinone derivatives compounds are biologically important compounds. Pyridazinone has carbonyl group on third carbon on pyridazine ring. Pyridazine and pyridazinone is a wonder nucleus because their derivatives give amost all types of biological activities such as such as analgesic, antiinflammatory, antimicrobial, antisecretory, antiulcer, antidepressants, neuroleptics, anxiolytics, sedative, hypnotic, tranquillizer, anticonvulsant, antiplatelet, antithrombotics, anticancer, antihistamine, cardiotonics, vasodilatators, antiarrhythmics, antidiabetic, antihypertensive, antitubercular and various other types of activities. These compounds are synthesized with the aim of novel agents those possess interesting biological activities. The present review has been focused on the pyridazine and pyridazinone derivatives with potential pharmacologica activities.
\end{abstract}

Keywords: Pyridazines, pyridazinones, pharmacoogical activities

\section{INTRODUCTION}

Pyridazine and Pyridazinone derivatives are belong to an important group of heterocyclic compounds, both containing two nitrogen atoms at adjacent position in a six member ring. Currently, there has been an increased interest in the pyridazine and pyridazinone compounds because their derivatives are one of the most active classes of compounds that possess wide spectrum of pharmacological activities. The pyridazine and pyridazinone compounds have been reported as diverse pharmacological active compounds. Substantial number pyridazine and pyridazinone derivatives represent an important class of biologically active compounds and possess interesting wide spectrum of biological activities such as antimicrobial, antiviral, antibacterial, antifungal analgesic, anti-inflammatory, antifeedant, herbicidal [1-3], antihypertensive, antiplatelet, anticancer, antipyretics, cardiovascular, antitubercular, anticonsulvant, intermediates for drugs and agrochemicals and other anticipated pharma-cological activities [4-6]. Pyridazine and pyridazinones drew our interest because of their easy functionalization at ring, which makes them effective compounds for designing and development of novel pharmacotherapeutic agents.

\section{Chemistry}

Pyridazine and pyridazinone compounds have two nitrogen atoms in a six member ring, both nitrogen atoms are present adjacent position and attached with single bond is most favourable form. Pyridazinone is a form of pyridazine with carbonyl group on third carbon [7].

\section{Analgesic and Antiinflammatory}

Many studies have been focused on pyridazine and pyridazinone compounds as non-steroidal anti-inflammatory drugs (NSAIDs), which possess analgesic [8] and anti-inflammatory activities very low ulcerogenicity. Among the different pyridazine and pyridazinone derivatives, 4-ethoxy-2-methyl-5-morpholino-3(2H)-pyridazinone (emorfazone) is being marketed as pentoil and nandron in Japan as analgesic and anti-inflammatory drug. The 4-amino-2-methyl-6-phenyl-5-vinyl-3(2H)-pyridazinone (1) was seven time more potent than emorfazone [9]. Antinociceptive activities exhibited by the compounds having 2-substituted4,5-functionalized 6phenyl-pyridazinones, some compounds were found more potent than Emorfazone [10]. The 4,5-dihalo, 5-arylidene and 4-carbamoyl pyridazinones and 3-oxo-5-benzylidene-6-methyl-(4H)-2-substituted pyridazines posses analgesic activities [11]. The pharmacological testing of various pyridazinone derivatives having anti-inflammatory activity linked with non-narcotic analgesic activities have been

Copyright @ 2019: This is an open-access article distributed under the terms of the Creative Commons Attribution license which permits unrestricted use, distribution, and reproduction in any medium for non commercial use (NonCommercial, or CC-BY-NC) provided the original author and source are credited. 
reported $[12,13,14]$. The 2-substituted 4,5-dihalo-3(2H)-pyridazinone derivatives have good analgesic activity and without ulcerogenic side effects [15]. The 2-substituted 4,5-functionalized 6-phenyl-3(2H)-pyridazinone derivatives have potent analgesic activity with negligible common side effects of currently used NSAIDs [16]. The 3-O-substituted benzyl pyridazinone derivatives were exhibited potent anti-inflammatory activity. The heterocyclic ring substitutions at six position, and the presence of acetamide side chain that is linked to the lactam nitrogen of pyridazinone ring at two position of pyridazinone ring raised the analgesic and anti-inflammatory action with nil or low ulcerogenic effects. The structurally different amide derivatives of [6-(3,5-dimethyl-4-chloro-1-pyrazolyl)-3(2H)pyridazinone]acetic acid (2) as analgesic and anti-inflammatory agents [17].<smiles>CCOc1c(N2CCOCC2)cnn(C)c1=O</smiles>

Emorfazone (1)<smiles>C=Cc1c(-c2ccccc2)nn(C)c(=O)c1N</smiles>

(2)<smiles>CC(=O)OC(C)=O</smiles>

(3)

The dual inhibition of cyclooxygenase (COX) and 5-lypoxygenase (LOX) enzymes for treatment of inflammation and pain, [6(4-methoxyphenyl)-3(2H)-pyridazinone-2-yl] acetamide and propanamides and of 3-[1-(3-pyridazinyl)-5-phenyl-1H-pyrazole-3yl]propanoic acids (4) were showed potential analgesic activity. Some studies for developing COX-2 inhibitors have concentrated on the amide derivatives of currently used NSAIDs and these compounds selectively inhibited COX-2 but not COX-1. Vicinally disubstituted pyridazinones act as selective COX-2 inhibitors. The 2-(3,4-Difluoro-phenyl)-4-(3-hydroxy-3-methyl-butoxy)-5-(4methanesulfonyl-phenyl)-2H-pyridazin-3-one (ABT-963), has good selectivity ratio (276:1, COX-2/COX-1), high oral anti-inflammatory activity in vivo, and gastric safety. ABT-963 reduced PGE2 production and reduced the edema. ABT-963 is a selective COX-2 inhibitor that may have efficacy in the treatment of the pain and inflammation linked with arthritis [18].<smiles>O=C(O)CCc1cc(-c2ccccc2)n(-c2cccnn2)n1</smiles>

(4)<smiles>CC(C)(O)CCOc1c(-c2ccc(S(C)(=O)=O)cc2)cnn(-c2ccc(F)c(F)c2)c1=O</smiles>

ABT-963

The 4,6-diphenyl-2-[3-(4-arylpiperazin-1-yl)propyl]-3(2H)-pyridazinones (5), inspired from tradazone a antidepressant drug, were more potent than acetaminophen and noramidopyrine in a p-benzoquinone-induced writhing test. The 2-substituted 4,5-dihalopyridazinones had high analgesic activity. 6-(4-methoxyphenyl)-pyridazinone derivatives carrying acetamide and propanamide moieties at position 2 of the pyridazinone ring and 1-[3-[6-(4-methoxyphenyl)-pyridazinon-2-yl]propanoyl]-4-(4-fluorophenyl)piperazine (6) had good analgesic activity.The 6-substituted-pyridazinones, 6-[4-(4-fluorophenyl)] piperazine-3(2H)-pyridazinones exhibited analgesic activity. The 4,6-diphenyl-3(2H)-pyridazinones substituted by 4-arylpiperazin-1-yl-carbonylalkyl moieties on the nitrogen atom in the 2 position of the pyridazinone ring tested as analgesic and anti-inflammatory.<smiles>CCCCCN1CCN(CCCn2nc(-c3ccccc3)cc(-c3ccccc3)c2=O)CC1</smiles>

(5)<smiles>COc1ccc(-c2ccc(=O)n(CCC(=O)N3CCN(c4ccc(F)cc4)CC3)n2)cc1</smiles>

(6) 
The vicinally disubstituted pyridazinones were potent and selective COX-2 inhibitors. Phosphodiesterase-4 (PDE-4) inhibitors are effective anti-inflammatory drugs, although some adverse effects are observed. Heterocyclic-fused pyridazinones that inhibited PDE-4 and act as anti-inflammatory agent. They reduced the paw edema induced by zymosan in mice as rolipram (the PDE4 inhibitor prototype with anti-inflammatory activity) and indomethacin did. Rolipram locally administered induces some adverse effects such as hyperalgesia. The effect after local use of 6-Benzyl-3-methyl-4-phenylpyrazolo[3,4-d]pyridazin-7(6H)-one (7), ethyl 6,7dihydro-6-ethyl-3-methyl-7-oxo-4-phenyl-thieno [2,3-d]pyridazine-2-carboxylate (8) and ethyl 6,7-dihydro-6-ethyl-3-methyl-4-phenyl$1 \mathrm{H}$-pyrrolo[2,3-d]pyridazine-2-carboxylate (9). Compound 8 induced hyperalgesic effects, whereas compound 7 and compound 9 did not exhibited hyperalgesic effects. Furthermore, rolipram and compound 8 reduced locomotor activity, whereas compound 7 and compound 9 did not change locomotor performance. The compound 7 and compound 8 neither affected the nociceptive threshold nor changed the locomotor performance, they appear more suitable than compound $\mathbf{9}$ could be developed as an anti-inflammatory drug.<smiles>Cc1n[nH]c2c(=O)n(Cc3ccccc3)nc(-c3ccccc3)c12</smiles>

7<smiles>CCOC(=O)c1sc2c(=O)n(CC)nc(-c3ccccc3)c2c1C</smiles>

8<smiles>CCOC(=O)c1[nH]c2c(c1C)C(c1ccccc1)=NN(CC)C2</smiles>

9

A series of 4-amino-pyridazinones substituted at position 2 with arylpiperazinylalkyl groups were exhibited antinociceptive effect. The 4-amino-pyridazinone compound to be almost 40-times more potent than the Emorfazone. The antihypertensive 5methyl-6-p.cyanophenyl-4,5-dihydro-3(2H)-pyridazinone has been embodied to a 4,4a-dihydro-5H-indeno[1,2-c]-3-pyridazinonic structure. The 7-cyano derivative was found to be devoid of antihypertensive activity. However this compound, and other 7-cyano derivatives were exhibited antiinflammatory properties. The pyridazinone derivative induced antinociception [16]. The 6-substituted$3(2 \mathrm{H})$-pyridazinone-2-acetyl-2-(p-substituted benzal) hydrazones were tested for analgesic and anti-inflammatory agents. Some compounds were exhibited more potent than standard drugs asprin and indimethacin for analgesic and anti-inflammatory activity. None of the compounds showed gastric ulcerogenic effect compared with reference NSAIDs [19]. Structurally diverse amide derivatives of 3-[1-(3-pyridazinyl)-5-phenyl-1H-pyrazole-3-yl]propanoic acids (10) were tested for their in vivo analgesic activity using an acetic acid induced writhing test. All the test compounds exhibited about equipotent analgesic activity to aspirin [20].<smiles>O=C(O)CCc1cc(-c2ccccc2)n(-c2cccnn2)n1</smiles>

(10)<smiles>[R]C(=O)CCc1cc(-c2ccc(Cl)cc2)n(-c2ccc([R])nn2)n1</smiles>

(11)

$\mathrm{R}=\mathrm{Cl}, \mathrm{R}_{1}=$ Amino phenyl derivatives, piprazine derivatives, amino alkyl derivatives .

The structurally diverse amide derivatives of [6-(3,5-dimethyl-4-chloro-pyrazole-1-yl)-3(2H)-pyridazinone-2-yl]acetic acid (12a-c) were tested for their in vivo analgesic and anti-inflammatory activity were found to be equipotent to aspirin (analgesic) and indometacin (anti-inflammatory) drugs. The other amide derivatives generally resulted in lower activity on comparision with reference compounds [17].<smiles>[R]C(=O)CC1C=C(n2nc(C)c(Cl)c2C)C=CC1=O</smiles> 
A series of 2-(4-substituted piperazin-I-ylmethyl)-6-(thien-2-yl)-2H-pyridazin-3-ones (13a-f) were exhibited anti-inflammatory activity [21].<smiles>[R]CCN1CCN(C(=O)Cn2nc(-c3ccc(OC)cc3)ccc2=O)CC1</smiles>

13a $n=1,2$<smiles>[R]CCN1CCN(C(=O)n2nc(-c3cccs3)ccc2=O)CC1</smiles>

$13 b$<smiles>[R]CCN1CCN(Cn2nc(-c3cccs3)ccc2=O)CC1</smiles>

$13 c$<smiles>[R]CCN1CCN(C(=O)CSc2ccc(-c3cccs3)nn2)CC1</smiles><smiles>[R7]CCN1CCN(C)CC1</smiles>

13d

$13 f$<smiles>[R]N1CCN(C(=O)CCSc2ccc(-c3cccs3)nn2)CC1</smiles>

$13 e$

$\mathrm{R}=\mathrm{CH}_{3}, \mathrm{C}_{2} \mathrm{H}_{5}, \mathrm{C}_{6} \mathrm{H}_{5}, \mathrm{CH}_{2} \mathrm{C}_{6} \mathrm{H}_{4}, \mathrm{p}-\mathrm{FC}_{6} \mathrm{H}_{4}, 2$-pyridyl, $\mathrm{R}_{1}=4-\mathrm{F}-\mathrm{CH}_{3}, 2$-pyridyl, $\mathrm{C}_{2} \mathrm{H}_{5}, \mathrm{R}_{2}=\mathrm{CH}_{2} \mathrm{C}_{6} \mathrm{H}_{4}, \mathrm{C}_{6} \mathrm{H}_{5}$

Some 3-Oxo-5-benzylidene-6-methyl-(4H)-2-substitutedpyridazines (14a) with antinociceptive and antiinflammatory activities were tested by using in vivo tests. One compound was exerting anti-inflammatory effect as potent as phenylbutazone and antinociceptive effect similar to acetylsalicylic acid [22].<smiles>CC(C)(O)CCOc1c(-c2ccc(S(C)(=O)=O)cc2)cnn(-c2ccc(F)c(F)c2)c1=O</smiles><smiles>CC(C)COc1c(-c2ccc(S(N)(=O)=O)cc2)cnn(-c2ccc(F)c(F)c2)c1=O</smiles>

ABT-963<smiles>CC(=O)O[R20](F)(F)c1ccc(-n2ncc(-c3ccc(S(C)(=O)=O)cc3)c(-c3ccc(F)cc3)c2=O)cc1</smiles>

A-241611<smiles>[X]c1cnn([R])c(=O)c1[X]</smiles>

$14 \mathrm{X}=\mathrm{Cl}, \mathrm{Br}$ 
A series of 2-(6-oxo-3,5-diphenyl-6H-pyridazin-1-yl)-acetamides (15) and 3-[6-oxo-3,5-diphenyl-6Hpyridazin-1-yl)propanamides (16) were tested for their analgesic and anti-inflammatory activities. Most of the compounds were more potent than aspirin in a $p$-benzoquinone-induced writhing test at $100 \mathrm{mg} / \mathrm{kg}$ dose and had the good anti-inflammatory activity; one compound was the most potent in terms of analgesic and anti-inflammatory activities and had no ulcerogenic side effects [23].<smiles>[R]C(=O)CN1N=C(c2ccccc2)C=C(c2ccccc2)C1=C</smiles>

15<smiles>C=C1C(c2ccccc2)=CC(c2ccccc2)=NN1CC(=O)N1CCN(P)CC1</smiles>

$16 \mathrm{R}=$ piprazine, $\mathrm{n}=1,2$

For reducing gastrointestinal toxicity linked with NSAIDs, some 6-phenyl/(4-methylphenyl)-3(2H)-pyridazinon-2propionamide were exhibited analgesic and anti-inflammatory activities. The 6-Phenyl-3(2H)-pyridazinon-2-yl-[4-(4-fluorophenyl) piperazinyl]propanamide (17) was the most active compound. None of the compounds showed gastric ulcerogenic effect compared with the reference NSAIDs [24]. Various pyridazinone derivatives bearing an arylpiperazinyl alkyl chain were tested. The most potent compound in this series was about 3-4 fold higher with respect to morphine. The analgesic effect was totally reversed by pretreatment with yohimbine both in the hot plate test and in the tail flick test [25]. A series of 2-substituted 4,5-functionalized 6-phenyl-3(2H)pyridazinones were tested for antinociceptive activities, some compounds were more active than the reference drug [26].<smiles>NC(=O)C(CN1CCN(c2ccc(F)cc2)CC1c1ccccc1)n1ncccc1=O</smiles>

17

\section{Effects on Cardiovascular system}

The inotropic and vasodilatory properties of 4,5-dihydro-6-phenylpyridazinones are well known [27, 28, 29]. Pyridazinone derivatives like SK\&F-93741, its normethyl derivative and levosimendan possess a substituted amino group at para-position of 6phenyl ring and have emerged as potent cardiotonic agents with dual inotropic and vasodilatory actions [30, 31]. These pyridazinone based cardiotonics have assured in the treatment of congestive heart failure (CHF) [32]. The potency of pyridazinone based cardiotonics result from varying para-substituents of the phenyl ring attached to 4-position of pyridazinone [33]. However, position 2 of the pyridazinone ring remains unexplored [27]. Besides, arylsubstituted-4,5-dihydropyridazinones such as imazodan are reported to show ionotropic properties comparable to milrinone and amrinone [34]. Pyridazinones combine positive inotropics and vasodilating properties. These drugs have shown that many are relatively selective inhibitors of a cytosolic form of cardiac cyclic nucleotide PDE activity $[35,36,37]$. The $\mathrm{Ca}^{2+}$ sensitizers, a class of cardiotonic agents, have shown positive inotropic effects without increasing intracellular $\mathrm{Ca}^{2+}$ transient. They avoid $\mathrm{Ca}^{2+}$ overload that leads to arrhythmias and myocyte injury, and do not increase the energy consumption for handling $\mathrm{Ca}^{2+}$. The $\mathrm{Ca}^{2+}$ sensitizers may be useful for the treatment of heart failure. However, most of the $\mathrm{Ca}^{2+}$ sensitizers may impair cardiac diastolic function as a result of raised $\mathrm{Ca}^{2+}$ sensitivity of the myofilaments. MCl-154, 6-[4-(4'pyridylamino)phenyl]-4,5-dihydro-3(2H)-pyridazinone hydrochloride trihydrate, is a calcium sensitizer that has more potent positive inotropic effect than that of pimobendan, adibendan and sulmazole [38, 39]. Over the past few years, a number of pyridazine derivatives have been applied to antiarrhythmics and antianginals [40]. Effects of Cardiotonic Drugs $\mathrm{Ca}^{2+}$ sensitizers, exert positive inotropic effects without increasing intracellular $\mathrm{Ca}^{2+}$ transient. They avoid $\mathrm{Ca}^{2+}$ overload that leads to arrhythmias and myocyte injury and do not raise the energy use for handling $\mathrm{Ca}^{2+}$. The $\mathrm{Ca}^{2+}$ sensitizers are useful for the treatment of heart failure. $\mathrm{MCl}-154$ has been confirmed to improve not only cardiac systolic function but also diastolic relaxation in chronic heart failure [39]. 
<smiles>[R6]c1ccc(-c2nc3cc(C4=NNC(=O)CC4C)ccc3[nH]2)cc1</smiles>

Pimobedan<smiles>COc1cc(S(C)=O)ccc1-c1nc2ccccc2[nH]1</smiles>

Sulmazole

The 2-substituted-6-(4-acylaminophenyl)-4,5-dihydropyridazin-3(2H)-ones as good inodilating agents. 6-(4Methanesulfonamidophenyl)-2-phenyl-4,5-dihydropyridazin-3(2H)-one (18) exhibited important inodilatory properties [34].<smiles>CC(=O)Nc1ccc(C2=NNC(=O)CC2C)cc1</smiles>

Sk\&f-93741<smiles>CC1CC(=O)NN=C1c1ccc(NN=C(C#N)C#N)cc1</smiles><smiles>[R]C1CC(=O)N([R])N=C1c1ccc(NS(C)(=O)=O)cc1</smiles>

$18 \mathrm{R}=$ phenyl, p-floro phenyl, imidazolyl, $\mathrm{H} \mathrm{R}_{1}=\mathrm{H}, \mathrm{CH}_{3}$

Levosimendan increases myocardial contractility by stabilizing the calcium bound conformation of troponin $\mathrm{C}$. In addition to its cardiac effects, it is also a vasodilator. This positive inotropic and vasodilator action is beneficial in rising cardiac output and decreasing left ventricular diastolic pressure, right atrial pressure and systemic vascular resistance in congestive heart failure patients [41]. The $\mathrm{Ca}^{2+}-$ sensitizing agents is an ideal cardiac inotropes. $\mathrm{MCl}-154$ is a potent PDE inhibitory effect. $\mathrm{MCl}-154$ induced a progressive dose-dependent decrease in systemic vascular resistance, with a concomitant increase in heart rate and cardiac output. The pyridazinone derivative $\mathrm{MCl}-154$ has minimal inotropic action, induces a significant "oxygen waste", and reduced vascular resistance in intact pigs [42]. Levosimendan is a inotropic $\mathrm{Ca}^{2+}$ sensitizer and a vasodilator. At high levels of stimulation, levosimendan reduced force without changing or increasing $\mathrm{Ca}^{2+}$. In contrast PDE-III inhibitor milrinone. Levosimendan relaxes coronary arteries and lowers $\mathrm{Ca}^{2+}$ by mechanisms different than milrinone. Lowering of $\mathrm{Ca}^{2+}$ by levosimendan by opening of $\mathrm{K}$ channels that is independent of $\mathrm{Ca}^{2+}[43,44]$.

Pimobendan, a benzimidazole-pyridazinone derivative in pigs with normal coronary circulation caused dose-dependent changes in heart rate, left ventricular systolic pressure, left ventricular filling pressure but had only a minor effect on the maximum rate of rise of left ventricular pressure. The decrease in mean arterial B.P was primarily due to systemic vasodilation; peripheral resistance and cardiac output decreased, respectively. Pimobendan is thus a compound with vasodilator and positive inotropic properties that improves cardiac output in animals with severe myocardial ischaemia [45]. The positive inotropic 4,5-dihydro-6-[2-(4-methoxyphenyl)$1 \mathrm{H}$-benzimidazol-5-yl]methyl-3(2H)-pyridazinone (19) enhances calcium induced contraction of skinned fibres from cardiac muscle probably by increasing the calcium sensitivity of troponin [46].The acute systemic hemodynamic effects of the calcium antagonist pyridazinone-derivative pimobendan, a PDE inhibitor with vasodilating as well as positive inotropic properties, were studied in conscious pigs with chronic heart failure. The vasodilatory and positive inotropic properties shifted more in favor of the vasodilatory actions during heart failure [47].<smiles>COc1ccc(-c2nc3cc(CC4=NNC(=O)CC4)ccc3[nH]2)cc1</smiles> 
The cardiovascular effects of 6-[4-[2-[3-(5-chloro-2-cyanophenoxy)-2-hydroxypropyl amino]-2-methylpropylamino]phenyl]4,5-dihydro-5-methyl-3(2H)pyridazinone mono ethyl maleate (salt) TZC-5665 and its main metabolite in human, M-2 was showed negative chronotropic and inotropic effects, whereas M-2 showed a potent positive inotropic effect with a slight positive chronotropic effect. The positive inotropic effect of M-2 was not modified by phentolamine, propranolol and cimetidine, but completely depressed by carbachol. In blood-perfused dog heart preparations, M-2 increased the contractile force and coronary blood flow of paced papillary muscles and sinus rate. The rate of ventricular automaticity was slightly increased by M-2, but suppressed by TZC-5665 at higher doses. TZC-5665 showed a non-selective $\beta$-adrenoceptor blocking activity comparable to that of propranolol in guinea-pig atrial and tracheal preparations. In enzyme preparations, TZC-5665 and M-2 were more potent and selective inhibitors of PDE III than milrinone. Combination of beta-adrenoceptor blocking effect of TZC-5665 and positive inotropic effect of M-2 could be useful in the treatment of CHF by mutual prevention of undesirable effects [48]. The TZC-5665 is a vasodilatory and beta-adrenergic blocking activities and PDE III inhibitory action. Its main metabolite, M-2, remained at a higher concentration in plasma. TZC-5665 reduced end-diastolic left ventricular volume. These effects appeared more potent in the failed heart than in the normal heart. At the same dose $(30 \mu \mathrm{gs} / \mathrm{kg})$, the effects of M-2 seem to be more potent than those of milrinone. The TZC-5665 is a useful medication for treating patients with chronic CHF because of the positive inotropic and vasodilating effects due to its active metabolite in addition to its own $\beta$-adrenergic blocking effects [49].<smiles>[Z20]C(C)(S)C(C)(CNc1ccc(C2=NNC(=O)CC2C)cc1)NCC(COc1cc(Cl)ccc1C#N)OC(=O)/C=C\C(=O)OCC</smiles>

Pimobendan is a calcium-sensitizing property that increases myocardial contractile force without increasing intracellular calcium. Pimobendan significanty improve exercise capacity and quality of life in patients with heart failure. The pimobendan may have a useful adjunctive role in heart failure. Pyridazinone derivatives having a phenoxy-propanolamine moiety showed hypotensive and $\beta$-blocking activities. Among them, the 5-chloro-2-cyanophenoxy derivative showed the promising dual activities [50]. The 6phenyl-4,5-dihydropyridazinone derivatives were exhibited cardiotonic activity [30]. Vasodilatory actionv of some amide derivatives of 6-(4-carboxymethyloxyphenyl)-4,5-dihydro-3(2H)-pyridazinone (19), substitution at 2-position of pyridazinone ring increses vasodilatory potential and most potent compound was 6-[4-(2-0xo-2-pyrrolidin-1-yl-ethoxy)phenyl]-2-(4-fluorophenyl)-4,5-dihydropyridazin-3(2H)-one (20) [51].<smiles>O=C(O)COc1ccc(C2=NNC(=O)CC2)cc1</smiles>

20<smiles>O=C(COc1ccc(C2=NN(c3ccc(F)cc3)C(=O)CC2)cc1)N1CCCC1</smiles>

21

The 6-phenyl-4,5-dihydro-3(2H)-pyridazinones, 2,3-dichloro-N-(4-(4-methyl-6-oxo-1,4,5,6-tetrahydro-pyridazin-3-yl) phenyl) benzamide (22), 4-amino-3-methyl-N-(4-(4-methyl-6-oxo-1,4,5,6-tetrahydro pyridazin-3-yl) phenyl)benzamide (23), 3-methyl-4-nitro-N(4-(6-oxo-1,4,5,6-tetrahydro-pyridazin-3-yl)phenyl)benzamide (24) and 4-amino-3-methyl-N-(4-(6-oxo-1,4,5,6-tetrahydro-pyridazin-3yl)phenyl) benzamide (25) were exhibited cardiotonic activities [52]. The 2-nonsubstituted/2-methyl-/2-(2-acetyloxyethyl)-6-[4(substituted pyrrol-1-yl)phenyl]-4,5-dihydro-3(2H)-pyridazinone derivatives were exhibited antihypertensive effects [53]. 
<smiles>CC1CC(=O)NN=C1c1ccc(NC(=O)c2cccc(Cl)c2Cl)cc1</smiles>

22<smiles>Cc1cc(C(=O)Nc2ccc(/C=N/N)cc2)ccc1N</smiles><smiles>Cc1cc(C(=O)Nc2ccc(C3=NNC(=O)CC3)cc2)ccc1[N+](=O)[O-]</smiles>

24

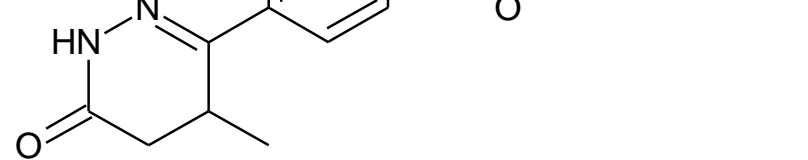

23

Positive inotropic and PDE inhibitory activity of the 4,5-dihydro-3(2H)-pyridazinone series were reported [32]. MCl-154 potentiated isometric tension and improved isometric tension cost at full $\mathrm{Ca}^{2+}$ activation. It showed little $\mathrm{Ca}^{2+}$-sensitizing effect. In contrast to its effect on cardiac muscle, however, $\mathrm{MCl}-154$ decreased all the kinetic parameters [54]. Some peptidomimetics containing 6-aryl-4,5-dihydropyridazazinones were exhibited antiplatelet action. The 6-Aryl-4,5-dihydro-pyridazinones were exhibit a potent, antiplateles and antihypertensive activities. The antiplatelet action of dihydropyridizinonyl peptidomimetics has been better to the simple dihydropyridezinones. The presence of halogen (chlorine) in 4-aryl group and a methyl group in pyridezinone have shown to potentiate the antiplatelet effect [55]. The effects of 2-(2 dimethylaminoethyl) 5-benzylidene 6-methyl (2H,4H)-3-pyridazinone (26) on the biosynthesis of TXA2 and PGI2. Biosyntheses of TXA2 and PGI2 were carried out using arachidonic acid (AA) as a substrate and platelet and aorta microsomes as sources of TXA2 and PGI2 synthetases. These compounds did not extensively modify either the biosynthesis of PGI2 or the PGI2 synthetase activity of heart tissue and did not considerably inhibit TXA2 biosynthesis but markedly reduced the TXA2 synthetase activity of heart tissue. Thus compounds behave as a inhibitor of the TXA2 synthetase activity of heart tissue [113]. The effects of 6-(2,3,4,5-tetrahydro-5-methyl-3-oxo-pyridazine-6-yl)-1,2,3,4-tetrahydro-1-methyl quinolin-2-one (Y-590) on platelet PDE. Y-590 potently inhibited CAMP-PDE in platelets, but its inhibitory effect on CGMP-PDE was less potent. The Y-590 is a selective inhibitor of CAMP-PDE which exerts its anti-platelet activity by inhibiting cAMP degradation in platelets [56].<smiles>CC1=NN(CCN(C)C)C(=O)C/C1=C/c1ccccc1</smiles>

26<smiles>CC1CC(=O)NN=C1c1ccc2c(c1)CCC(=O)N2C</smiles>

The 6-(alpha alpha-diphenyl acetylpiperazinyl) phenyl-5-methyl-4,5-dihydro-3 (2H)-pyridazinone (27) was shown to inhibit AA, ADP and PAF-induced platelet aggregation. This compound was depressing TXB2 content and to raise CAMP levels in washed rabbit platelets in a dose-dependent manner [57]. The positive inotropic agent, 4,5-dihydro-6-[2-(4-methoxyphenyl)-1H-benzimidazol5-yl]methyl-3(2H)-pyridazinone (UD-CG $115 \mathrm{BS)}$ improves calcium induced contraction of skinned fibres from cardiac muscle possibly by enhancing the calcium sensitivity of troponin [46]. 
<smiles>[Z7]C(C)(C)[R15]([H])(C)(=O)CC1=NNC(=O)CC1</smiles>

An optically pure pyridazinone derivative was a nonprostanoid PGI2 agonist and inhibited ADP-induced aggregation of platelets [58]. The PC-09, a pyridazinone derivative, has antiplatelet activity. Pretreatment with PC-09 resulted in an inhibition on platelet aggregation and ATP release induced by AA, collagen or thrombin. The thromboxane $B 2$ formation caused by collagen or thrombin was inhibited by PC-09, but there was no change in that caused by AA. The PC-09 increased the cAMP level by inhibiting CAMP PDE activity. The PC-09 is an antiplatelet aggregation, which may be linked with inhibition of thromboxane A2 formation, intracellular calcium mobilization and platelet surface GPIIb/lla expression along with by rising cAMP level [59]. The 5-acyl-6-phenyl2,4-substituted-pyridaziones, with a sulfur stereogenic center, had the most potent activity as antiplatelet [26]. Some pyridazinone substituted benzenesulfonylurea derivatives were showed blood sugar lowering effect in normal and NIDDM (n2-STZ) rat models. Some compounds were exhibited significantly potent blood glucose lowering activity and may be used for developing new antidiabetic drugs [60].

The positive-inotropic and vasodilatating drug Pimobendan (racemate), 4,5-dihydro-6-[2-(4-methoxyphenyl)-1 $\mathrm{H}$ benzimidazole-5-yl]-5-methyl-3(2-H)-pyridazinone, and its enantiomers were reduced blood pressure [61]. Cardiac effect of pyridazinone derivative, TZC-5665 and its metabolite acts as a vasodilatory and beta-adrenergic blocking agents and type III PDE inhibitory agent. TZC-5665 was rapidly absorbed and immediately metabolized in M-2. Orally use of TZC-5665 reduced end-diastolic left ventricular volume. The cause M-2 dose-dependently increased cardiac contractility and reduced both preload and afterload. At the same dose, the M-2 was more potent than those of milrinone. TZC-5665 is a useful in chronic congestive heart failure (CHF) due to both positive inotropic and vasodilating action and beta-adrenergic blocking action of its metabolite [49]. The enantiomers of 5acetyl-2-methyl-4-methylsulfinyl-6-phenyl-3(2H)-pyridazinone act as a anti platelet aggregation agent [26]. The pyridazinone derivative, zardaverine is a selective inhibitor of PDE isozymes as a potent bronchodilator. The zardaverine used as positive inotropic agent on heart muscle. Zardaverine inhibited the cGMP-inhibitable PDE-III from human platelets and the rolipram-inhibitable PDE IV. The Zardaverine affected the calmodulin-stimulated PDE I, the cGMP-stimulated PDE-II and the cGMP-specific PDE-V. Zardaverine inhibits the ADP-induced aggregation of platelets. This inhibition was synergistically increased by activators of adenylate cyclase like PGE1 and forskolin. The zardaverine is a selective inhibitor of PDE-III and PDE-IV isozymes [62]. A optically pyridazinone derivative was act as a nonprostanoid PGI2 agonist and it inhibited ADP-induced aggregation of human platelets [58]. Pimobendan (UD-CG 115) is a cardiotonic vasodilator that increases myocardial contractility through calcium sensitization and relaxation of vascular smooth muscle due to PDE inhibition. Pimobendan is O-demethylated to UD-CG 212 and latter is metabolized to O- and N-glucuronides. Pimobendan itself is glucuronidated to an N-glucuronide [63].

\section{Antibacterial and antifungal activities}

The 5-Thioxo-1,2,4-triazole containing a pyridazinone side chain is an ideal heterocyclic system for antifungal activity. The 6substituted phenyl-2-[\{(4'-substituted phenyl-5'-thioxo)-1,2,4-triazol-3-yl\}-methyl]-2,3,4,5-tetra hydro pyridazin-3-one compounds (28) were exhibited antifungal activity against $C$. albicans, Trichophyton rubrum, Aspergillus flavus, $A$. niger and Penicillium citrinium. The chloro substituent compound was showed the highest activity against all the fungal species. The two electronegative groups of $\mathrm{Cl}$ were increasing the activity of 1,2,4-triazole [64]. A series of 6-anthracenepyridazinones containing indolyl moieties from indole to 6 anthracene-4-oxo-2-butenoic acid (29) were showed antibacterial activity [65]. 


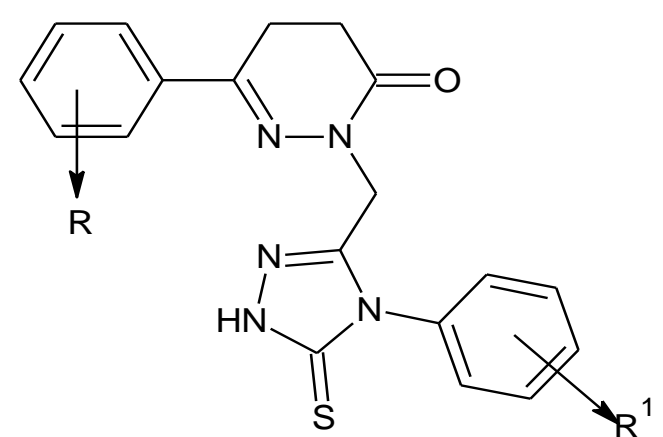

$28 \mathrm{R}=\mathrm{H}, \mathrm{CH}_{3}, \mathrm{Cl}, \mathrm{Br}, \mathrm{OCH}_{3}, \mathrm{C}_{6} \mathrm{H}_{5} \mathrm{O} \mathrm{R}^{1}=\mathrm{H}, \mathrm{p}-\mathrm{Cl}, \mathrm{p}-\mathrm{Br}$
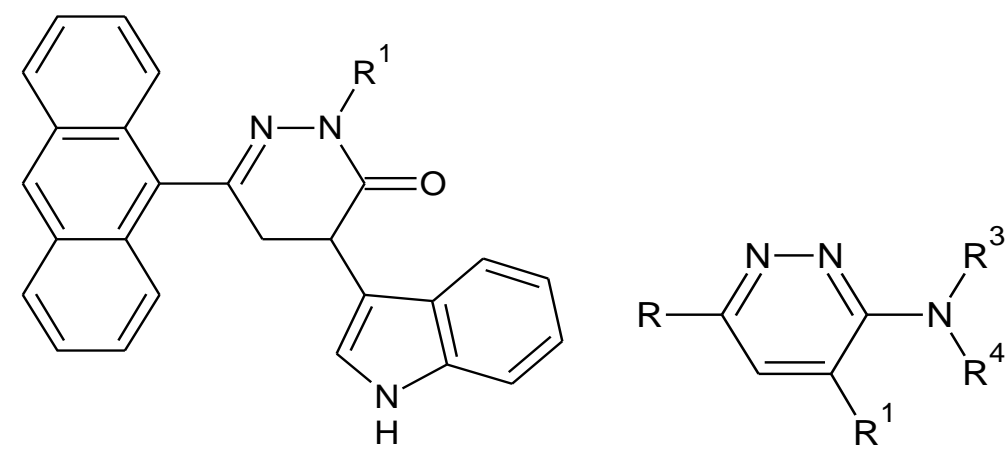<smiles></smiles>

29 (a-c) R= H, Ph, $\mathrm{CONH}_{2}, \mathrm{CSNH}_{2}$.<smiles>[R]c1ccc(NC)nn1</smiles><smiles>[R]c1ccc(CCCCCCCCC)nn1</smiles><smiles>[R]c1ccc(O)nn1</smiles><smiles>[R]c1ccc(NN)nn1</smiles><smiles>[R]c1ccc(-n2nc(C)cc2C)nn1</smiles>

29 (d-h) $\mathrm{R}=$ =Anthrecenyl, $\mathrm{R}_{1}=$ indolyl, $\mathrm{R}_{2}=\mathrm{C}_{4} \mathrm{H}_{9} \mathrm{O}, \mathrm{C}_{5} \mathrm{H}_{11} \mathrm{O}_{5}, \mathrm{C}_{11} \mathrm{H}_{21} \mathrm{O}_{10} . \mathrm{R}_{3}=\mathrm{H}, \mathrm{CH}_{3}, \mathrm{C}_{2} \mathrm{H}_{5}, \mathrm{C}_{6} \mathrm{H}_{5} \mathrm{R}_{4}=\mathrm{C}_{6} \mathrm{H}_{5},-4-\left(\mathrm{SO}_{3} \mathrm{H}\right) \mathrm{C}_{6} \mathrm{H}_{4}$, Naphyl,<smiles>[R]C1=NN(S(=O)(=O)c2ccc([P])cc2)C(=O)C([R7])C1</smiles><smiles>[R]C=C1C([R])=NNC(=O)C1[R]</smiles>

$29(\mathrm{i}-\mathrm{j}) \mathrm{R} 5=\mathrm{H}, \mathrm{CH}_{3}, \mathrm{R}_{6}=\mathrm{H}, \mathrm{CH}_{3}, \mathrm{C}_{6} \mathrm{H}_{5},-2-(\mathrm{OH}) \mathrm{C}_{6} \mathrm{H}_{4},-4-(\mathrm{OH}) \mathrm{C}_{6} \mathrm{H}_{4},-2-\left(\mathrm{OC}_{3} \mathrm{H}\right) \mathrm{C}_{6} \mathrm{H}_{4},-4-\left(\mathrm{OC}_{3} \mathrm{H}\right) \mathrm{C}_{6} \mathrm{H}_{4},-2,4-\left(\mathrm{OCH}_{3}\right)_{2} \mathrm{C}_{6} \mathrm{H}_{3},-2-(\mathrm{OH}) \mathrm{C}_{10} \mathrm{H}_{6}$, $\mathrm{C}_{4} \mathrm{H}_{3} \mathrm{O}$

A series of 2-[(4-substituted phthalazine-1-yl)alkyl]-1H-isoindole-1,3(2H)-diones (30) and 2-\{2-[4-(1,3-dioxo-1,3-dihydro-2H-isoindole2-yl-alkyl)1-oxophthalazine-2(1H)-yl] alkoxy\}-1H-isoindole-1,3(2H)-diones (31) were showed major antimicrobial activity. 
<smiles>[R]C(c1nn(CCON2C(=O)c3ccccc3C2=O)c(=O)c2ccccc12)N1C(=O)c2ccccc2C1=O</smiles><smiles>[R]C(c1nn(C)c(=O)c2ccccc12)N1C(=O)c2ccccc2C1=O</smiles><smiles>CN1C(=O)C2C3C=CC(C3)C2C1=O</smiles>

$3031 \mathrm{R}=\mathrm{H}, \mathrm{CH}_{3}$

Several 5-[1-aryl-1,4-dihydro-6-methylpyridazin-4-one-3-yl] -2-arylamino-1,3,4-thia-diazoles (32) were exhibited antifungal activity. A series of 5-[1-aryl-1,4-dihydro-6-methylpyridazin-4-one-3-yl]-2-arylamino-1,3,4-oxadiazoles were exhibited fungicidal activity against wheat leaf rust, Puccinia recondita and their activity was influenced by the nature of the substituents. The structure and activity relationship of the compounds, pyridazinone-substituted 1,3,4-thiadiazoles and the pyridazinone-substituted 1,3,4-oxadiazoles, 1,3,4oxadiazole ring is a bioisosteric analogue of the 1,3,4-thiadiazole ring [66]. Pyridazinone derivatives, corresponding dithio derivatives, thio derivativem and chloro derivatives (33-35) were showed antimicrobial and antifungal activities [67].<smiles>[R]Cc1cccc(Nc2[X]c(-c3nn(-c4ccccc4)c(C)cc3=O)nn2)c1</smiles><smiles>CC1=C(c2cc(-c3ccc(Cl)c(Cl)c3)n[nH]c2=S)C(=S)C(c2ccccc2)C1C</smiles>

$32 X=0, S$

33<smiles>[R]n1nc(-c2ccc(Cl)c(Cl)c2)cc(C2=C(C)C(C)C(c3ccccc3)C2=O)c1=O</smiles>

$34 \mathrm{R}=\mathrm{H}, \mathrm{C}_{6} \mathrm{H}_{5}$<smiles>CC1=C(c2cc(-c3ccc(Cl)c(Cl)c3)n[nH]c2=O)C(=O)C(c2ccccc2)C1C</smiles>

35 
Various metal complexes of 5-benzoyl-4-hydroxy-2-methyl-6-phenyl-2H-pyridazin-3-one were exhibited antimicrobial activities against Gram-positive, Gram-negative bacteria and fungi. The $\mathrm{Cd}(\mathrm{II})$ and $\mathrm{Ni}(\mathrm{II})$ complexes exhibited selective and effective activities against one Gram-positive bacterium $S$. aureus, one Gram-negative bacterium $P$. putida and against two yeast $C$. albicans and $C$. tropicalis in contrast to poor activity observed other microorganisms [68]. Chloropyridazine derivative were showed antibacterial activity [65]. The 4-Benzylamino-6-(5,5-dioxodibenzothiophen-2-yl)-2,3,4,5-tetrahydro pyridazin-3-ones as anti-microbial [69]. The 3-N-(phthalyl- or tosylamino acids) pyridazines (36) were exhibited antibacterial activities (Aly and Wasfy 2002).<smiles>[Y20]=O</smiles>

The 4-Cyano-3-oxido-1-beta-D-ribofuranosylpyridazinium is example of a mesoionic analogue of a pyrimidine nucleoside. It was obtained as a urine metabolite of 4-cyano-pyridazinone in mice. The 4-Cyano-3-oxido-1-beta-D-ribofuranosylpyridazinium possesses antibacterial activity against $E$. coli in mice. The 4-substituted 3-oxidopyridazinium ribonucleosides as analogue of 4Cyano-3-oxido-1-beta-D-ribofuranosylpyridazinium was several times more active than 4-Cyano-3-oxido-1-beta-D-ribofuranosylpyridazinium against E. coli [70]. Several pyridazinone and pyrazolethione analogs were inhibited sortase (SrtA) and exhibited antimicrbia activity [71].

\section{Anticovulsant activity}

The pyridazinones ring system agrees with salient feature for anticonvulsant activities. In order to explore the activity, various 6-arylpyridzinones were exhibited anticonvulsant activity [72]. The anticonvulsant activity of 5-substitutedbenzylidene-6methyl-4,5-dihydropyridazinones [73]. Some 6-(substituted-phenyl)-4,5-dihydropyridazinones and 6-(substitutedphenyl)-pyridazinones were exhibited anticonvulsant activity against MES induced seizures. Compounds have an electron withdrawing group on the phenyl ring exhibited considerable anticonvulsant activity [74]. The 1-substituted-1,2-dihydro-pyridazine-3,6-diones were exhibited anticonvulsant activity. Maximum protection against MES induced seizures were exhibited by compound 1-[3-(2-aminophenylamino)2-hydroxypropyl)-1,2-dihydropyridazine-3,6-dione, 2-hydroxy-3-piperazin1-yl-propyl)-1,2-dihydro-pyridazine-3,6-dione and 1-[2hydroxy-3-imidazol-1-yl-propyl)-1,2-dihydro-pyridazine-3,6-dione. Whereas all these compounds failed to protect the animals from pentylenetetrazole (Metrozol) induced seizures [75].

A series of 6-aryl-3-(hydroxypolymethyleneamino)pyridazines derivatives were tested for anticonvulsant activity against MES and bicuculline-induced seizures; and neurotoxicity. Phenobarbital, diphenylhydantoin, carbamazepine, and sodium valproate were used as standard antiepileptic drugs. The activities were affected by either varying the aryl ring in the 6-position of the pyridazine ring or by modifying the 3-amino side chain. Compounds with a phenyl ring in the 6-position of the pyridazine ring and 4-hydroxypiperidine side chain in the 3-position of the pyridazine ring appeared essential for activity. Substituting the phenyl ring with a $\mathrm{Cl}$ in the 2-position led to increase activity; disubstituting the phenyl ring with a $\mathrm{Cl}$ in the 2- and 4-positions yielded the most potent compounds in this series, some of which were as potent or more potent than phenobarbital. Two compounds, 6-(2-chlorophenyl)-3-(4hydroxypiperidino)pyridazine and 6-(2,4-dichlorophenyl)-3-(4-hydroxypiperidino)pyridazine were exhibited significant activities [76] Two amino-phenyl-pyridazine derivatives, SR 41378 and CM 40907 have antagonized seizures. Structurally, SR 41378 differs from CM 40907 by additional chlorine in position 6 of the phenyl ring and compared their activity with diazepam, pentobarbital, meprobamate and valproate [77].

The 3-amino-7-(2,6-dichlorobenzyl)-6-methyltriazolo[4,3-b]pyridazines PC25 contain amide or carboxylic acid function were tested for anticonvulsant activity. The compounds having the imidazole ring substituted with an amide group were more active against MES seizures. Maximum activity was linked with a 2,6-dichlorobenzyl substitution pattern. The 3-Amido-7-(2,6-dichlorobenzyl)-6methyl-triazolo [4,3-b]pyridazine was also defensive against PTZ-induced and strychnine-induced seizures [78]. Some 6-substituted pyridazinone ring derivatives $(\mathbf{3 7 , 3 8})$ were exhibited anticonvulsant activity against MES [72].
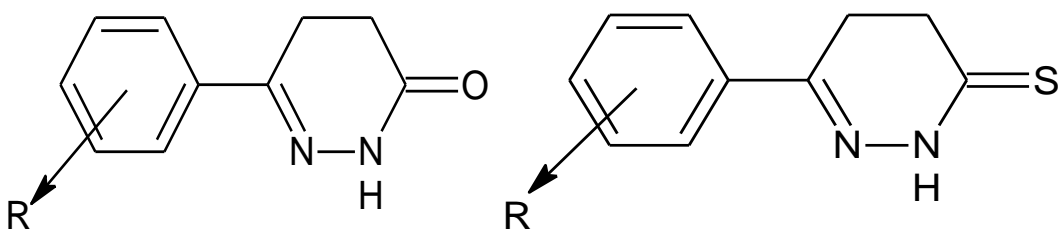

$3637 \mathrm{R}=$ benzene, toulene, ethylbenzene, anisol, o-xylene. 
The 5-benzylidene-6-methyl-4,5-dihydropyridazine-3(2H)-one (38) their ester, hydrazide and acetic acid derivatives were exhibited anticonvulsant activities by PTZ induced seizure. Some compound showed an anticonvulsant effect similar to ethosuximide [22].<smiles>[R]c1ccc(/C=C2/CC(=O)N(CC(=O)O)N=C2C)cc1</smiles>

$38 \mathrm{R}=\mathrm{H}, \mathrm{Br}, \mathrm{Cl}, \mathrm{CH}_{3}, \mathrm{OCH}_{3}$

\section{Atnitubercular activity}

Some pyridazinone and phthalazinone derivatives $(39,40)$ carrying $\mathrm{N}$-(phenylsulfonyl) acetohydrazide moiety at position 2 of these rings were exhibited antitubercular activity against M. tuberculosis H37 Rv. Unsubstituted compounds were more active than after the substitution of chlorine at the para position in the phenyl ring [79].<smiles>[R]c1ccc(Nc2ncccc2C(=O)NNS(=O)(=O)c2ccc([Y])cc2[X])c([R])c1</smiles>

39<smiles>[R]CC(=O)NNS(=O)(=O)c1ccc([R])cc1</smiles>

40

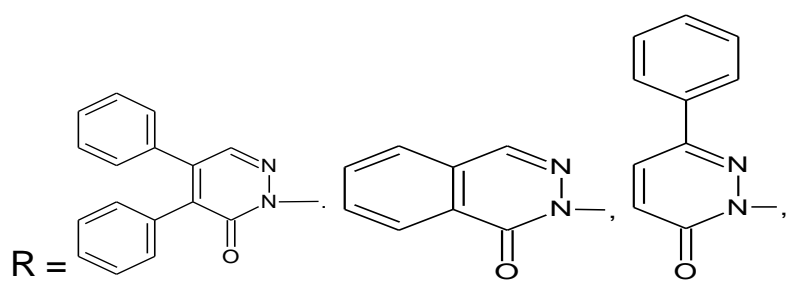

A series of 6-substituted phenyl-2-(3'-substituted phenyl pyridazin-6'-yl)-2,3,4,5-tetrahydropyridazin-3-ones $(\mathbf{4 1 , 4 2})$ were exhibited in vitro antitubercular activity. These compounds have mild to potent activities [80]. A series of 5-\{3'-oxo-6'-(substituted aryl)-2',3',4',5'tetrahydropyridazin-2'-ylmethyl\}-2-substituted 1,3,4-oxadiazole $(\mathbf{4 3 , 4 4 )}$ were exhibited antitubercular activity. All the compounds were screened at $6.25 \mu \mathrm{g} / \mathrm{mL}$ against $M$. tuberculosis $\mathrm{H} 37 \mathrm{Rv}$ [81]. Some $3(2 \mathrm{H})$-pyridazinone and $1(2 \mathrm{H})$-phthalazinones were exhibited antibacterial activity and antitubercular activity [79].<smiles>[R]c1ccc(C2=NN(c3ccc([R])nn3)C(=O)CC2)cc1</smiles><smiles>[R]c1ccc(C2=NN(c3ccc([R])nn3)C(=O)CC2)cc1</smiles> 
$41,42 \mathrm{R}=-\mathrm{C}_{6} \mathrm{H}_{5}, 4-\mathrm{CH}_{3} \mathrm{C}_{6} \mathrm{H}_{5}, 3,5-\left(\mathrm{CH}_{3}\right)_{2}-\mathrm{C}_{6} \mathrm{H}_{5}, \mathrm{C}_{11} \mathrm{H}_{9} \mathrm{O},-\left(\mathrm{C}_{6} \mathrm{H}_{5}\right)_{2} \mathrm{R}=\mathrm{H}, 3,5-\left(\mathrm{CH}_{3}\right) 2,4-\mathrm{Cl}-, 4-\mathrm{Br}, \mathrm{C}_{6} \mathrm{H}_{5}, \mathrm{p}-\mathrm{CH}_{3}, \mathrm{C}_{6} \mathrm{H}_{5} \mathrm{O}-$<smiles>[R]C1=NN(Cc2nnc(N)o2)C(=O)CC1</smiles><smiles>[R]C1=NN(Cc2nnc(Nc3ccccc3)o2)C(=O)CC1</smiles>

$\mathrm{R}=$ appropriate hydrocarbon, phenyl, p-tolyl, p-phenoxyphenyl, p-chlorophenyl.

\section{Anticancer activity}

The CDK inhibitors have garnered attention for their potential as anticancer agent [82, 83, 84]. Pyrazolopyridazine is a potent inhibitor of $C D K 1 /$ cyclin B. Series of pyrazolo[3,4-c]pyridazines of in an attempt to improve potency against the CDK family. Pyrazolopyridazine is also as a potent inhibitor of glycogen synthase kinase-3 (GSK-3) and CDK2/cyclin A [85], showed good selectivity against the tested kinases. The GSK-3 has a major role in the regulation of the cell cycle, transcription, and insulin action. The kinase inhibitors could be useful in the treatment of cancer [82, 86, 87]. The triazolo[4,3-b]pyridazinones, are used as adenine receptor ligands and in vitro antitumor activities was reported [88].

Pyrazolopyridazine as a potent inhibitor of (Cyclin-Dependent Kinases) CDK1/cyclin B and these compounds have been revealed antitumor activities [87]. Pyrido[4,3-b]carbazole-type alkaloids (43a-c) represents a 3-aza analog of the antitumor natural product, olivacine. Structural modifications of this compound type will be carried out, aiming at an improvement of antineoplastic activity [89].<smiles>Cc1c2[nH]c3ccccc3c2cc2c(CO)n[nH]c(=O)c12</smiles><smiles>Cc1n[nH]c(=O)c2c(C)c3[nH]c4ccccc4c3cc12</smiles><smiles>CC1=NNCc2c1cc1c([nH]c3ccccc31)c2C</smiles>

43a-c R= ethyl, n-propyl, n-butyl, n-pentyl, benzyl

New triazolo[4,3-b]pyridazinones (43a-c) were exhibited potential in vitro antitumor activities [88]. Some pyrrolo[3,4d]pyridazinones modified at the pyrrole and pyridazine rings were exhibited anticancer screenings. Few compounds blocked the cell cycle regulating CDK1/cyclin B kinase, were active in as anticancer agent [90]. The 5-benzyl-2,6-dimethylpyridazin-3(2H)-one have analgesic activity and anticancer activity [91].<smiles>[R7]OC(=O)C1=NN(c2ccc([R])cc2)C2([R])CCC(=O)NN12</smiles>

$44 \mathrm{R}_{1}=\mathrm{Cl}, \mathrm{NO}_{2}, \mathrm{CH}_{3}, \mathrm{OCH}_{3}, \mathrm{R}_{2}=\mathrm{CH}_{3}, \mathrm{C}_{6} \mathrm{H}_{5}$

\section{Effects on Central Nervous System}

N-bromomethyl derivatives of methyl pyridazinones, and 2,4-dimethyl-6-phenyl-3(2H)-pyridazinone [92] that selective suppression of neurotoxic products produced by extreme glial activation will result in neuroprotection. The 4,6-diphenyl-3-(4(pyrimidin-2-yl)piperazin-1-yl) pyridazine (MW01-5-188WH), a selective inhibitor of proinflammatory cytokine production by activated glia, suppressed the human amyloid- $\beta$ ( $A \beta$ ) induced upregulation of interleukin-1 $\beta$, and tumor necrosis factor-a. Alzheimer's disease $(A D)$ and other related neurodegenerative disesease is a main cause of disability and death [93, 94] and the hypothesis that targeting of neuroinflammation might be a therapeutic approach to altering disease sequence [95]. Orally bioavailable and brain-penetrant compound MW01-5-188WH that is an inhibitor of glial activation. The chronic treatment of mice with MW01-5-188WH suppresses proinflammatory cytokine reactions linked to AD-related pathophysiology, with resultant protection against hippocampus synaptic 
dysfunction and hippocampal-dependent behavioral deficits. The behavioral effects of two BZ (omega) receptor agonists, the pyridazinone Y-23684 and pyrido[1,2-a]benzimidazole RWJ-46771 with the BZs diazepam and clobazam for the testing of anxiolytic activity. Clobazam and Y-23684 considerably modified all defense responses at doses that did not reduced spontaneous locomotor activity. RWJ-46771 reduced risk estimation, avoidance responses, flight speed, and defensive threat and attack reactions. The $Y$ 23684 exhibited anxiolytic-like activity comparable to BZs. The RWJ-46771 considerably modified most defensive behaviors [96].<smiles>CCC(C)(C)S(C)(C)(=O)c1ccccc1-c1cc(-c2ccccc2)nnc1N1CCN(c2ncccn2)CC1</smiles>

The pharmacological properties of several BZ-omega receptor ligands, including the imidazobenzodiazepine imidazenil, the beta-carboline abecarnil, the pyridazinone Y-23684, the pyrido[1,2-a]benzimidazole RWJ 46771 and the 1,6-naphthyridin-2(1H)-one SX-3228, with the prototypical BZs diazepam, clobazam and bretazenil. All compounds increased the latency to clonic seizures produced by isoniazid (INH). The maximal increase in latency induced by diazepam, clobazam, abecarnil, RWJ 46771 and SX-3228 was greater than that of bretazenil, imidazenil and Y-23684. Diazepam, clobazam and imidazenil elicited clear anxiolytic-like effects. The bretazenil and Y-23684 induced anxiolytic-like activity at much lower doses than those which impaired motor performances. The effects of Y-23684 was similar to that of the BZs, it may a valuable alternative to currently used antianxiety drugs. Abecarnil, RWJ 46771 and SX-3228 produced weaker or non-specific anxiolytic-like effects as they decreased anxiety-related behaviours. The behavioural profiles of abecarnil, RWJ 46771 and SX-3228 may be recognized to their selectivity for the BZ-omega 1 receptor subtype which may for their sedative activity, thereby masking other effects including anxiolytic-like activity. The BZ receptor modulation of anxiety may involve BZ receptor subtypes other than BZ-omega1 [97]. The methyl 3-methoxy pyridazine derivatives, depends on the substitutions, various selectivities have been observed, including atypical N-methyl bromination. A rapid method for predicting the selectivity of reactions used in the synthesis of pyridazine analogues of the neurotransmitters GABA and glutamate [92]. The M73101 decreased spontaneous locomotor activity and prolonged sleeping time induced by hexobarbital. M73101 did not inhibit convulsions induced by MES and PTZ but slightly inhibited the convulsion induced by strychnine in mice. These properties of M73101 on the CNS are similar to aminopyrine though the potency was weaker. M73101 like aminopyrine showed no marked activity on the motor function. The pharmacological properties of a permeability transition pore inhibitor, 5-(benzylsulfonyl)-4-bromo-2-methyl-3(2H)pyridazinone (BBMP). The mitochondrial PTP is potentially involved in neuronal cell death and that permeability transition pore (PTP) inhibitors, like BBMP, may possess a therapeutic potential in neurodegenerative disorders [98]. The piperazine-pyridazinones, arylpiperazine moiety were evaluated for their influence in determining the affinity of the compounds toward the alpha1-adrenergic

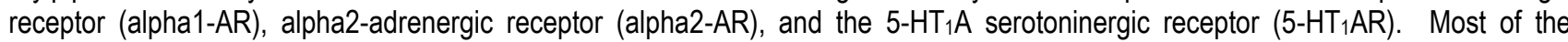
compounds have an alpha1-AR affinity in nanomolar or subnanomolar range, while affinity toward the other two receptors was lower in most cases [99].

\section{Anti asthma \& antiallergy activity}

The effects of pyridazinone derivative, NZ-107, 4-bromo-5-(3-ethoxy-4-methoxybenzylamino)-3(2H)-pyridazinone, and two known antiasthmatic drugs, amlexanox and disodium cromoglycate (DSCG) on antigen-, histamine- and leukotriene C4 (LTC4)induced constriction of isolated tracheal muscle, and histamine release from lung tissues and leukocytes were examined. Salbutamol was used as a reference drug. NZ-107 inhibited antigen-, histamine- and LTC4-induced contraction of tracheal muscle. Amlexanox inhibited the IL-3-induced enhancement of histamine release from leukocytes in the case of both stimuli, but NZ-107 and DSCG had no effect. The NZ-107 has potent anti-allergic actions based on the inhibition of antigen-induced contraction of tracheal muscle and mediator release from lung tissue and leukocytes [100]. The effect of NZ-107, on bronchoconstriction induced by slow reacting substance of anaphylaxis (SRS-A). Orally used NZ-107 inhibited antigen-induced SRS-A-mediated broncho constriction. NZ-107 prevented the antigen-induced response about as well as the SRS-A antagonist FPL-55712 and rapidly reversed it. NZ-107 more selectively inhibited the LTD4 response than those of histamine, acetylcholine and KCl. Compared to FPL-55712, NZ-107 was onefifteenth less potent in inhibiting the LTD4 response, but two-fold more potent in inhibiting the LTC4 response. NZ-107 inhibited the LTD4 response of the trachea 10-fold more potently than that of the ileum. NZ-107 is a selective inhibitor of the SRS-A response and may be useful in the therapy of bronchial asthma and other diseases in which the LTs are thought to be involved [101]. 
<smiles>CCOc1cc(CNc2cn[nH]c(=O)c2Br)ccc1OC</smiles>

NZ-107

Effect of 4-chloro-5-(3-ethoxy)-4-phenoxybenzamine)-pyridazinone, [NIP-502] on antigen-induced bronchial responses and allergic reactions. NIP-502 inhibited the antigen-induced immediate asthmatic response. NIP-502 improved ovalbumin (OA)-induced airway hyper responsiveness to acetylcholine (Ach) and inhibited the OA-induced increase in inflammatory leukocytes in the broncho alveolar lavage fluid. These inhibitory effects on OA-induced responses were similar to those of prednisolone. NIP-502 considerably inhibited Formyl-Met-Leu-Phe-induced superoxide anion formation by alveolar macrophages. The inhibitory effects of NIP-502 on bronchial responses are similar to those of prednisolone, this compound act more selectively on the respiratory tract than prednisolone. So its effectiveness against a variety of bronchial responses, NIP-502 may be useful in the treatment of bronchial asthma [102].

\section{Miscellenous activities}

A series of benzyl pyridazinones were act as HIV-1 non-nucleoside reverse transcriptase inhibitors (NNRTIs). Some compounds were showed good activity against the wild-type virus and NNRTI resistant viruses. The Oxadiazolyl 3(2H)-pyridazinones (45) have increased lipophilicity relative to the 2,5-disubstituted-1,3,4-oxadiazole and act as antifeedent agent. The 2,4,5Trisubstituted-3(2H)-pyridazinones (46) are used in agrochemicals and pharmaceuticals. 1,3,4-oxadiazoles were exhibited effective insecticides toward houseflies, faceflies and hornflies. These compounds inhibit chitin synthesis in Drosophlia and in Musca domestica [40]. A series of 5-[1-aryl-1,4-dihydro-6-methylpyridazin-4-one-3-yl]-2-arylamino-1,3,4-oxadiazoles (47) were exhibited fungicidal activity in vivo against wheat leaf rust, Puccinia recondite. The oxadiazolyl $3(2 \mathrm{H})$-pyridazinone gave mortality levels of $100 \%$ against $P$. recondita at $500 \mathrm{ppm}$. The oxadiazolyl-3(2H)-pyridazinones (ODP) were exhibited insect antifeedant activities against Asiatic corn borer Ostrinia furnacalis (Guenee) and compared with azadirachtin.<smiles>O=c1ccc(-c2ncc(NO)o2)n[nH]1</smiles>

45<smiles>O=c1cc(OCc2ccc(Cl)nc2)cnn1-c1ccc(Cl)c(Cl)c1</smiles>

47<smiles>Cc1c(SCc2ccc(C(C)(C)C)cc2)cnn(C(C)(C)C)c1=O</smiles>

46<smiles>[X]Cc1nnc([R])o1</smiles>

$48 X=0, S R=$ aryl

The oxadiazolyl 3(2H)-pyridazinone (ODP) is a insect growth regulator, on growth of larvae of the armyworm, Pseudaletia separata Walker (Lepidoptera: Noctuidae). The ODP inhibited the growth of $P$. separata, causing slowed development and prolonged larval period, smaller body size and sluggish behavior, delayed pupation and reduced eclosion rate of pupae and adults. Moreover, 
ODP inhibited the activities of trypsine-like enzyme, chymotrypsin-like enzyme and alpha amylase in the $P$. separata larvae, and inhibited the activity of alpha amylase. The ODP has severe cost on the larval carbohydrate absorption and/or nutrient intake and causes inhibition of larval growth. [103]. The some pyridazinone compounds were showed molluscicidal activity towards Biomphalaria alexandrina snails [104]. Some a,a,a-trifluoro-m-tolyl pyridazinone derivatives and its some intermediates were showed herbicidal activities against Spirodela polyrrhiza (L.).

The 5-amino-4-chloro-2-phenyl-3(2H)-pyridazinone (Chloridazon) is an herbicide compound [112]. Use of 12-day-old winter wheat (Triticum aestivum) plants with 4-chloro-5 (dimethylamino)-2-phenyl-3(2H)-pyridazinone (BASF 13-338) 36 hours before frost hardening concurrently and fully inhibits addition of linolenic acid in the roots during the hardening period and the gaining of frost resistance. BASF 13-338 prevents the increase in per cent dry weight in roots and shoots during hardening and causes a decrease in root lipid phosphorus and total fatty acids. Norflurazone, 4-chloro-5-(mthylamino)-2-(alfa,alfa,aalfa-trifloro-m-tolyl)-3-(2H)-pyridazinone and fluorinated phenol pyridazinone was used as herbicide. The HCV NS5B polymerase inhibitors derived from 4-(10,10-dioxo-10,40dihydro-10k6- benzo[10,20,40]thiadiazin-30-yl)-5-hydroxy-2H-pyridazin-3-ones [105].

Some pyridazinone compounds were showed insecticidal activities against Aphis rumicis Linnaeus [106]. A pyridazino-fused ring system: pyridazino[3,4-b][1,5]diazepam were exhibited some pharmacological activities [107]. The interaction between a pyridazinone derivative (5-chloro-2-nitro-N-(4-(6-oxo-1,4,5,6-tetrahydropyridazin-3-yl)phenyl)benzamide (CNPB) and human serum albumin (HSA) has been investigated [52]. BMS-747158-02 in cardiomyocytes: a PET myocardial imaging agent, BMS-747158-02 is a fluorine 18-labeled pyridazinone derivative designed for cardiac imaging. It is a positron emission tomography cardiac tracer targeting MC-I in cardiomyocytes with rapid uptake and slow washout [108]. Hypericin has photosensitizing and tumouritropic activity, but at the same time exhibits minimal dark toxicity. This compound is a photosensitizer in clinical photodynamic therapy (PDT). Hypericin derivatives have an advantage over the parent compound by being photo-activated by red light, which penetrates deeper into tumour tissue. Three hypericin derivatives (dibenzoxazole, pyridazinone, and dibenzthiazole) have a potent photocytotoxic effect under whitelight. These derivatives are only poor photosensitizers when used under red-light [109]. The pyridazinone-based as 5-HT(2C) agonists [7]. Pyridazinone derived compound with excellent levels of 5- $\mathrm{HT}(2 \mathrm{C})$ functional agonism and selectivity over 5-HT(2A) and 5-HT(2B) and exhibited good efficacy in stress urinary incontinence [110]. Diaryl pyridazine-3-ones evaluated as aldose reductase inhibitory activity [111].

\section{DISCUSSION}

The pyridazine ring plays an essential role in several biological processes. Likewise, these are found to be associated with significant industrial uses, potential biological and physiological activities. Accordingly a massive research effort has been expended the novel congeners bearing these biologically active structural moieties within a molecular framework likely to constitute potent pharmacological agents $[4,5,6]$. Polysubstituted pyridazinones from tetrafluoropyridazine and 4,5,6-trifluoropyridazin-3(2H)-one can be used for the synthesis of various substituted and ring-fused pyridazinones. A variety of polyfunctional systems can be readily accessed by substitution process which may have applications in the drug discovery arena. Pyridazinones hold extensive interest relative to the formation of organic intermediates and physiologically active compounds [1, 2, 3].

\section{CONCLUSION}

The literature reveals that pyridazine/pyridazinone has diverse biological potential, and has taken attention of the chemists, pharmacologists and researchers. The analgesic, anti-inflammatory, antimicrobial, anticonvulsant, anticancer and antitubercular, cardiotonic activities are the most encouraging activities for the pharmacists. This diversity in the pharmacologically response profile has attracted the attention of many researchers to explore this nucleus to its multiple potential against several activities. After that pyridazinone derivatives have studied extensively and have diverse chemical reactivities and diverse biological activities. By the present scenario, pyridaziinone have a great potential which remain to be disclosed till date. The biological profile of these generations of pyridazinones represents much progress with regards.

\section{REFERENCES}

1. Asif, M. (2012). Some recent approaches of biologically active substituted pyridazine and phthalazine drugs. Current medicinal chemistry, 19(18), 2984-2991.

2. Asif, M. (2013). Antifeedant, herbicidal and molluscicidal activities of pyridazinone compounds. Mini-Reviews in Organic Chemistry, 10(2), 113-122.

3. Asif, M. (2014). A mini review on biological activities of pyridazinone derivatives as antiulcer, antisecretory, antihistamine and particularly against histamine H3R. Mini reviews in medicinal chemistry, 14(13), 1093-1103..

4. Asif, M. (2016). Biological Potential and Chemical Properties of Pyridine and Piperidine Fused Pyridazine Compounds: Pyridopyridazine a Versatile Nucleus. Asian Journal of Chemistry and Pharmaceutical Sciences, 1(1), 29-35.

5. Asif, M. (2016). The biological potentials of substituted 1, 2-diazines: a review on versatile pyridazine derivatives. Journal of Chinese Pharmaceutical Sciences, 10(001).

6. Asif, M. (2018). Diverse Biologically Active Pyridazine Analogs: A Scaffold for the Highly Functionalized Heterocyclic Compounds. Review Journal of Chemistry, 8(3), 280-300. 
7. Anwair, M. A., Károlyházy, L., Szabó, D., Balogh, B., Kövesdi, I., Harmat, V., ... \& Mátyus, P. (2003). Lipophilicity of aminopyridazinone regioisomers. Journal of agricultural and food chemistry, 51(18), 5262-5270.

8. Giovannoni, M. P., Vergelli, C., Ghelardini, C., Galeotti, N., Bartolini, A., \& Dal Piaz, V. (2003). [(3-Chlorophenyl) piperazinylpropyl] pyridazinones and analogues as potent antinociceptive agents. Journal of medicinal chemistry, 46(6), 10551059.

9. Dal Piaz, V., Giovannoni, M. P., Ciciani, G., Barlocco, D., Giardina, G., Petrone, G., \& Clarke, G. D. (1996). 4, 5-Functionalized 6phenyl-3 (2H)-pyridazinones: synthesis and evaluation of antinociceptive activity. European journal of medicinal chemistry, 31(1), 65-70.

10. Dal Piaz, V., Giovannoni, M. P., Ciciani, G., Barlocco, D., Giardina, G., Petrone, G., \& Clarke, G. D. (1996). 4, 5-Functionalized 6phenyl-3 (2H)-pyridazinones: synthesis and evaluation of antinociceptive activity. European journal of medicinal chemistry, 31(1), 65-70.

11. Ayla, B., Fügen, Ö., Oya, Ü., Zafer, G., \& Berna, T. (2003). Studies on Some 3-Oxo-5-benzylidene-6-methyl-(4H)-2substitutedpyridazines with Antinociceptive and Antiinflammatory Activities. FABAD J Pharm Sci, 28, $19-25$.

12. Abignente, E., De Caprariis, P., Rimoli, M. G., Avallone, L., Paloma, L. G., Rossi, F., ... \& Parrillo, C. (1993). Research on heterocyclic compounds. XXXI. Synthesis and antiinflammatory activity of 2-arylimidazo [1, 2-a] pyrazine-3-carboxylic acids. European journal of medicinal chemistry, 28(4), 337-346.

13. Pinna, G. A., Sardu, F., Curzu, M. M., Satta, M., Peana, A., Cignarella, G., \& Barlocco, D. (1992). Synthesis and pharmacological activity of 4-carbamoyl-5-aryl-6-methyl-4, 5-dihydropyridazin-3 (2H)-ones. Farmaco (Societa chimica italiana: 1989), 47(4), 449463.

14. Flouzat, C., Bresson, Y., Mattio, A., Bonnet, J., \& Guillaumet, G. (1993). Novel nonopioid non-antiinflammatory analgesics: 3(aminoalkyl)-and 3-[(4-aryl-1-piperazinyl) alkyl] oxazolo [4, 5-b] pyridin-2 (3H)-ones. Journal of medicinal chemistry, 36(4), 497503.

15. Santagati, N. A., Duro, F., Caruso, A., Trombadore, S., \& Amico-Roxas, M. (1985). Synthesis and pharmacological study of a series of $3(2 \mathrm{H})$-pyridazinones as analgesic and antiinflammatory agents. II Farmaco; edizione scientifica, 40(12), 921-929.

16. Pieretti, S., Dal Piaz, V., Matucci, R., Giovannoni, M. P., \& Galli, A. (1999). Antinociceptive activity of a 3 (2H)-pyridazinone derivative in mice. Life sciences, 65(13), 1381-1394.

17. Süküroglu, M., Ergün, B. Ç., Sahin, M. F., Küpeli, E., Yesilada, E., \& Banoglu, E. (2005). Synthesis, analgesic, and antiinflammatory activities of [6-(3, 5-dimethyl-4-chloropyrazole-1-yl)-3 (2H)-pyridazinon-2-yl] acetamides. Archives of pharmacal research, 28(5), 509-517.

18. Harris, R. R., Black, L., Surapaneni, S., Kolasa, T., Majest, S., Namovic, M. T., ... \& Marsh, K. (2004). ABT-963 [2-(3, 4-difluorophenyl)-4-(3-hydroxy-3-methyl-butoxy)-5-(4-methanesulfonyl-phenyl)-2H-pyridazin-3-one], a highly potent and selective disubstituted pyridazinone cyclooxgenase-2 inhibitor. Journal of Pharmacology and Experimental Therapeutics, 311(3), $904-912$.

19. Goekce, M., Colak, M. Ş., Kiipeli, E., \& Şahin, M. F. (2009). Synthesis and analgesic and anti-inflammatory activity of 6-phenyl/(4methylphenyl)-3 (2H)-pyridazinon-2-propionamide derivatives. Arzneimittelforschung, 59(07), 357-363.

20. Banoğlu, E., ŞÜKÜROĞLU, M., ERGÜN, B. Ç., BAYTAŞ, S. N., Aypar, E., \& ARK, M. (2007). Synthesis of the amide derivatives of 3-[1-(3-pyridazinyl)-5-phenyl-1H-pyrazole-3-yl] propanoic acids as potential analgesic compounds. Turkish Journal of Chemistry, 31(6), 677-687.

21. Refaat, H. M., Khalil, O. M., \& Kadry, H. H. (2007). Synthesis and anti-inflammatory activity of certain piperazinylthienylpyridazine derivatives. Archives of pharmacal research, 30(7), 803.

22. Oya, U., Ayla, B., Cenk, A., Berna, T. M., \& Zafer, G. (2004). Synthesis and evaluation of the anticonvulsant activities of some 5(4-substitutedbenzylidene)-6-methyl-4, 5-dihydro pyridazine-3 (2H)-ones. FABAD J. Pharm. Sci, 29, 185-194.

23. DOĞRUER, D. S., ŞAHIN, M. F., Küpeli, E., \& YEŞILADA, E. (2003). Synthesis and analgesic and anti-inflammatory activity of new pyridazinones. Turkish Journal of Chemistry, 27(6), 727-738.

24. Gökçe, M., Utku, S., \& Küpeli, E. (2009). Synthesis and analgesic and anti-inflammatory activities 6-substituted-3 (2H)pyridazinone-2-acetyl-2-(p-substituted/nonsubstituted benzal) hydrazone derivatives. European journal of medicinal chemistry, 44(9), 3760-3764.

25. Biancalani, C., Giovannoni, M. P., Pieretti, S., Cesari, N., Graziano, A., Vergelli, C., ... \& Garrone, B. (2009). Further studies on arylpiperazinyl alkyl pyridazinones: discovery of an exceptionally potent, orally active, antinociceptive agent in thermally induced pain. Journal of medicinal chemistry, 52(23), 7397-7409.

26. Azzolina, O., Dal Piaz, V., Collina, S., Giovannoni, M. P., \& Tadini, C. (1997). Chiral resolution and absolute configuration of the enantiomers of 5-acetyl-2-methyl-4-methylsulfinyl-6-phenyl-3 (2H)-pyridazinone and evaluation of their platelet aggregation inhibitory activity. Chirality, 9(7), 681-685.

27. Lee, S. G., Kim, J. J., Kim, H. K., Kweon, D. H., Kang, Y. J., Cho, S. D., ... \& Yoon, Y. J. (2004). Recent progress in pyridazin-3 (2H)-ones chemistry. Current Organic Chemistry, 8(15), 1463-1480.

28. Abouzid, K., Hakeem, M. A., Khalil, O., \& Maklad, Y. (2008). Pyridazinone derivatives: Design, synthesis, and in vitro vasorelaxant activity. Bioorganic \& medicinal chemistry, 16(1), 382-389.

29. Abou-Zeid, K. A. M., Youssef, K. M., Shaaban, M. A., El-Telbany, F. A., \& Al-Zanfaly, S. H. (1997). Synthesis of 6-(4(Substituted-amino) phenyl)-4, 5-dihydropyridazin-3 (2H) ones As Potential Positive Inotropic Agents. Egyptian journal of pharmaceutical sciences, 38(4-6), 319-331. 
30. Wang, T., Dong, Y., Wang, L. C., \& Chen, Z. (2007). Synthesis and bioactivity of 6-phenyl-4, 5-dihydro-3 (2H)-pyridazinone derivatives. Arzneimittelforschung, 57(10), 641-646.

31. Archan, S., \& Toller, W. (2008). Levosimendan: current status and future prospects. Current Opinion in Anesthesiology, 21(1), 78-84.

32. Sircar, I., Morrison, G. C., Burke, S. E., Skeean, R., \& Weishaar, R. E. (1987). Cardiotonic agents. 6. Synthesis and inotropic activity of 2, 4-dihydro-5-[4-(1H-imidazol-1-yl) phenyl]-3H-pyrazol-3-ones: ring-contracted analogs of imazodan (Cl-914). Journal of medicinal chemistry, 30(10), 1724-1728.

33. Owings, F. F., Fox, M., Kowalski, C. J., \& Baine, N. H. (1991). An enantioselective synthesis of SK\&F 93505, a key intermediate for preparing cardiotonic agents. The Journal of Organic Chemistry, 56(5), 1963-1966.

34. Kumar, D., Carron, R., La Calle, C., Jindal, D., \& Bansal, R. (2008). Synthesis and evaluation of 2-substituted-6-phenyl-4, 5dihydropyridazin-3 (2H)-ones as potent inodilators. Acta pharmaceutica, 58(4), 393-405.

35. Weishaar, R. E., Burrows, S. D., Kobylarz, D. C., Quade, M. M., \& Evans, D. B. (1986). Multiple molecular forms of cyclic nucleotide phosphodiesterase in cardiac and smooth muscle and in platelets: isolation, characterization, and effects of various reference phosphodiesterase inhibitors and cardiotonic agents. Biochemical pharmacology, 35(5), 787-800.

36. Ahn, H. S., Eardley, D., Watkins, R., \& Prioli, N. (1986). Effects of several newer cardiotonic drugs on cardiac cyclic AMP metabolism. Biochemical pharmacology, 35(7), 1113-1121.

37. Kariya, T., Wille, L. J., \& Dage, R. C. (1984). Studies on the mechanism of the cardiotonic activity of MDL 19205: effects on several biochemical systems. Journal of cardiovascular pharmacology, 6(1), 50-55.

38. KITADA, Y., MORITA, M., \& NARIMATSU, A. (1989). Comparison of the effects of MCl-154, a new cardiotonic agent, and some $\mathrm{Ca} 2+-$ sensitizing agents on the response of the contractile system to $\mathrm{Ca} 2+$ in skinned cardiac muscle. The Japanese Journal of Pharmacology, 50(4), 411-419.

39. Chen, H. Z., Cui, X. L., Zhao, H. C., Zhao, L. Y., Lu, J. Y., \& Wu, B. W. (2004). Inotropic effects of MCl-154 on rat cardiac myocytes. Sheng li xue bao:[Acta physiologica Sinica], 56(3), 301-305.

40. Tao, J., Wang, D. Z., \& Cao, L. H. (2007). Synthesis of 5-(6-Pyridazinone-3-yl)-2-Glycosylamino-1, 3, 4-Oxadiazoles. Journal of the Chinese Chemical Society, 54(5), 1287-1292.

41. Montes, F. R., Echeverri, D., Buitrago, L., Ramírez, I., Giraldo, J. C., Maldonado, J. D., \& Umaña, J. P. (2006). The vasodilatory effects of levosimendan on the human internal mammary artery. Anesthesia \& Analgesia, 103(5), 1094-1098.

42. Korvald, C., Nordhaug, D. O., Steensrud, T., Aghajani, E., \& Myrmel, T. (2002). Vasodilation and Mechanoenergetic Inefficiency Dominates the Effect of the" Ca 2+-sensitizer" MCl-154 in Intact Pigs. Scandinavian Cardiovascular Journal, 36(3), 172-179.

43. Bowman, P., Haikala, H., \& Paul, R. J. (1999). Levosimendan, a calcium sensitizer in cardiac muscle, induces relaxation in coronary smooth muscle through calcium desensitization. Journal of Pharmacology and Experimental Therapeutics, 288(1), 316325.

44. Uhlmann, R., Schwinger, R. H. G., Lues, I., \& Erdmann, E. (1995). EMD 53998 acts as Ca 2+-sensitizer and phosphodiesterase III-inhibitor in human myocardium. Basic research in cardiology, 90(5), 365-371.

45. Verdouw, P. D., Hartog, J. M., Duncker, D. J., Roth, W., \& Saxena, P. R. (1986). Cardiovascular profile of pimobendan, a benzimidazole-pyridazinone derivative with vasodilating and inotropic properties. European journal of pharmacology, 126(1-2), 21-30.

46. Rüegg, J. C., Pfitzer, G., Eubler, D., \& Zeugner, C. (1984). Effect on contractility of skinned fibres from mammalian heart and smooth muscle by a new benzimidazole derivative, 4, 5-dihydro-6-[2-(4-methoxyphenyl)-1H-benzimidazol-5-yl]-5-methy l-3 (2H)pyridazinone. Arzneimittel-forschung, 34(12), 1736-1738.

47. Duncker, D. J., Roelandt, J. R., \& Verdouw, P. D. (1989). Acute hemodynamic effects of nisoldipine and pimobendan in conscious pigs with chronic heart failure. Journal of cardiovascular pharmacology, 14(4), 653-658.

48. Ishimori, T., Gotanda, K., Sasaki, T., Shinbo, A., Asano, H., Miyazawa, K., \& Miyasaka, K. (1994). Cardiac effects of the novel pyridazinone derivative 6-[4-[2-[3-(5-chloro-2-cyanophenoxy)-2-hydroxypropylamino]-2-methylpropylamino] phenyl]-4, 5-dihydro5-methyl-3 (2H) pyridazinone monoethyl maleate and its metabolite in isolated heart preparations of guinea pigs and dogs. Arzneimittel-Forschung, 44(5), 583-588.

49. Araki, S. L., Uematsu, T., Nagashima, S., Matsuzaki, T., Gotanda, K., Ochiai, H., ... \& Nakashima, M. (1997). Cardiac and hemodynamic effects of TZC-5665, a novel pyridazinone derivative, and its metabolite in humans and dogs. General pharmacology, 28(4), 545-553.

50. Seki, T., Nakao, T., Masuda, T., HASUMI, K., GoTANDA, K., ISHIMORI, T., ... \& YASUDA, K. (1996). Studies on agents with vasodilator and $\beta$-blocking activities. IV. Chemical and pharmaceutical bulletin, 44(11), 2061-2069.

51. Bansal, R., Kumar, D., Carron, R., \& de la Calle, C. (2009). Synthesis and vasodilatory activity of some amide derivatives of 6-(4carboxymethyloxyphenyl)-4, 5-dihydro-3 (2H)-pyridazinone. European journal of medicinal chemistry, 44(11), 4441-4447.

52. Wang, T., Dong, Y., Wang, L.C., Xiang, B.R., Chen, Z, Qu, L.B. (2008). Design, synthesis and structure-activity relationship studies of 6-phenyl-4,5-dihydro-3(2H)-pyridazinone derivatives as cardiotonic agents. Arzneimittelforschung 58(11), 569-73.

53. Demirayak, S., Karaburun, A.C., Beis, R. (2004). Some pyrrole substituted aryl pyridazinone and phthalazinone derivatives and their antihypertensive activities. European Journal of Medicinal Chemistry, 39(12), 1089-95.

54. Iwamoto, H., (1998). Effect of a cardiotonic agent, MCl-154, on the contractile properties of skinned skeletal muscle fibers. European Journal of Pharmacology, 341(2-3), 243-52. 
55. Eddy, S., Alberto, C., Enrique, R. (2003). Pyridazine Derivatives 321): Stille-Based Approaches in the Synthesis of 5-Substituted6-phenyl-3(2H)-pyridazinones. A series of 6-phenyl-3(2H)-pyridazinones bearing different substituents in the 5-position of the pyridazinone ring were prepared using Stille-based approaches in the search for new platelet-aggregation inhibitors. Chemistry Pharmaceutical Bulletin, 51(4), 427-430.

56. Mikashima, H., Nakao, T., Goto, K., Ochi, H., Yasuda, H., Tsumagari, T. (1984). Y-590 (a new pyridazinone derivative), a potent anti-thrombotic agent-II. Inhibition of platelet phosphodiesterase. Thromb Research, 35(5), 589-94.

57. Zeng, G.Q., Wang, X.S., Sun, D.X., Lin, A.Y, Ji, Y., Chu, J.X., Rui, Y.C. (1993). Effects of 6-(alpha alphadiphenylacetylpiperazinyl) phenyl-5-methyl-4,5-dihydro-3 (2H)-pyridazinone on rabbit platelet aggregation and TXB2, cAMP production. Yao Xue Xue Bao, 28(4), 256-9.

58. Tsubaki, K., Taniguchi, K., Tabuchi, S., Okitsu, O., Hattori, K., Seki J, Sakane, K., Tanaka, H. (2000). A novel pyridazinone derivative as a nonprostanoid PGI2 agonist. Bioorganic Medicinal Chemistry Letters, 10 (24), 2787-90.

59. Cherng, S.C., Huang, W.H., Shiau, C.Y., Lee, A.R., Chou, T.C. (2006). Mechanisms of antiplatelet activity of PC-09, a newly synthesized pyridazinone derivative. European Journal of Pharmacolology, 532(1-2), 32-7.

60. Rathish, I.G., Javed, K., Bano, S., Ahmad, S., Alam, M.S., Pillai, K.K. (2009). Synthesis and blood glucose lowering effect of novel pyridazinone substituted benzenesulfonylurea derivatives. European Journal of Medicinal Chemistry, 44(6), 2673-8.

61. Schneider, P., Güttner, J., Eckenfels, A., Heinzel, G., von Nicolai, H., Trieb, G., Lehmann, H. (1997). Comparative cardiac toxicity of the i.v. administered benzimidazole pyridazinon derivative Pimobendan and its enantiomers in female Beagle dogs. Experimental Toxicology \& Pathology, 49(3-4), 217-24.

62. Schudt, C., Winder, S., Müller, B., Ukena, D. (1991). Zardaverine as a selective inhibitor of phosphodiesterase isozymes. Biochemistry \& Pharmacology, 42(1), 153-62.

63. Pahernik, S.A., Schmid, J., Sauter, T., Schildberg, F.W., Koebe, H.G. (1995). Metabolism of pimobendan in long-term human hepatocyte culture: in vivo-in vitro comparison. Xenobiotica, 25(8), 811-23.

64. Anees, A.S., Syed, R.A., Mohammed, S.M., Syed, A.H., Mohammed, R., Ravindra, K. (2008). Synthesis and in-vitro antifungal activity of 6-substituted-phenyl-2-\{[(4i-substituted phenyl-5í-thioxo)-1,2,4-triazol-3-yl]-methyl\}-2,3,4,5-tetrahydropyridazin-3-one derivati- ves. Acta Pol Pharm, 65(2), 223-228.

65. Abubshait, S.A. (2007). An efficient synthesis and reactions of novel indolylpyridazinone derivatives with expected biological activity. Molecules, 12(1), 25-42.

66. Xia-Juan, Z., Lu-Hua, L., Gui-Yu, J., Zu-Xing, Z. (2002). Anti microbial Synthesis, Fungicidal Activity, and 3D-QSAR of Pyridazinone-Substituted 1,3,4-Oxadiazoles and 1,3,4-Thiadiazoles. Journal of Agriculture \& Food Chemistry, 50(13), $3757-3760$.

67. Sayed, G.H., Hamed, A.A., Meligi, G.A., Boraie, W.E., Shafik, M. (2003). The Use of 4-(3,4-Dichlorophenyl)-4-Oxo-2-(4Antipyrinyl)-Butanoic Acid in the Preparation of Some New Heterocyclic Compounds With Expected Biological Activity. Molecules, 8, 322-332.

68. Sonmez, M., Berber, I., Akbas, E. (2006). Synthesis, antibacterial and antifungal activity of some new pyridazinone metal complexes. European Journal Medicinal Chemistry, 41(1), 101-5.

69. Ashraf, A. F. W., Mohamed, M. H. A., Mahassen, S. A., Shafey, G. D., Aly, A. A. (2001). Y-Oxo Carboxylic Acids in Heterocyclic Synthesis, III. Synthesis of Biologically Active 4-Benzylamino-6-(5,5-dioxodibenzothiophen-2-yl)-2,3,4,5-tetrahydropyridazin-3ones. 2002, Verlag der Zeitschrift fur Naturforschung, 669-676.

70. Bambury, R. E., Feeley, D. T., Lawton, G. C., Weaver, J. M., \& Wemple, J. (1984). Mesoionic pyridazine ribonucleosides. A novel biologically active nucleoside metabolite. Journal of medicinal chemistry, 27(12), 1613-1621.

71. Suree, N., Yi, S.W., Thieu, W., Marohn, M., Damoiseaux, R., Chan, A., Jung, M.E., Clubb, R.T., 2009. Discovery and structureactivity relationship analysis of Staphylococcus aureus sortase A inhibitors. Bioorganic \& Medicinal Chemistry 17(20), 7174-85.

72. Pooja. S.B., Sharma, P.K., Rajesh, K.N. (2009). Synthesis and Anticonvulsant Activity of Pyridazinone Derivatives. International Journal ChemTech Research, 1(3), 522-525.

73. Rubat, C., Coudert, P., Albuisson, E., Bastide, J., Couquelet, J., Tronche, P. (1992). Synthesis of mannich bases of arylidenepyridazinones as analgesic agents. Journal of Pharmaceutical Sciences, 81, 1084-1087.

74. Xu, P., Wang, S.Y., Chen, Y., Liu, W.Q., Tao, C. (1991). Studies on synthesis, anticonvulsant activity and the structure-activity relationships of 6-(substituted phenyl)-3(2H)pyridazinones. Yao Xue Xue Bao, 26(9), 656-60.

75. Sivakumar, R., Anbalagan, N., Gunasekaran, V., Leonard, J.T. (2003). Synthesis and anticonvulsant activity of novel $1-$ substituted-1,2-dihydro-pyridazine-3,6-diones. Biological \& Pharmaceutical Bulletin, 26(10), 1407-11.

76. Hallot, A., Brodin, R., Merlier, J., Brochard, J., Chambon, J.P., Biziere, K., (1986). Synthesis and activity of 6-aryl-3(hydroxypolymethyleneamino)pyridazines in animal models of epilepsy. Journal of Medicinal Chemistry, 29(3):369-75.

77. Perio, A., Chambon, J.P., Calassi, R., Heaulme, M., Biziere, K. (1986). Evaluation of two anticonvulsant amino-pyridazine derivatives in the conflict test in rats. Journal of Pharmacology \& Experimental Therapy, 239(2), 542-7.

78. Moreau, S., Coudert, P., Rubat, C., Vallee-Goyet, D., Gardette, D., Gramain, J.C., Couquelet, J. (1998). Synthesis and anticonvulsant properties of triazolo- and imidazopyridazinyl carboxamides and carboxylic acids. Bioorganic Medicinal Chemistry, 6(7), 983-91.

79. Doğruer, D. S., Önkol, T., Özkan, S., Oezgen, S., \& ŞAHIN, M. F. (2008). Synthesis and antimicrobial activity of some 3 (2H)pyridazinone and $1(2 \mathrm{H})$-phthalazinone derivatives. Turkish Journal of Chemistry, 32(4), 469-479.

80. Mojahidul, I., Anees, A.S., Ramadoss, R., Afroz, B., Sunil, G. (2008). Synthesis and antimicrobial activity of some novel oxadiazole derivatives. Acta Pol Pharmaceutica, 65(3), 353-362 
81. Mojahidul, I., Anees, A.S., Ramadoss, R. (2008). Synthesis, antitubercular, antifungal and antibacterial activities of 6 -substituted phenyl-2-(3í-substituted phenyl pyridazin-6í-yl)-2,3,4,5-tetrahydropyridazin-3-one. Acta Pol Pharmaceutica, 65(4), 441-447.

82. Knockaert, M., Greengard, P., Meijer, L. (2002). Pharmacological Inhibitors of Cyclin-Dependent Kinases. Trends in Biochemcal Science, 23, 417-425.

83. Huwe, A., Mazitschek, R., Giannis, A. (2003). Small Molecules as Inhibitors of Cyclin-Dependent Kinases. Angew Chemistry, Intenational Edition. 42, 2122-2138.

84. Sielecki, T.M., Boylan, J.F., Benfield, P.A., Trainor, G.L. (2000). Cyclin Dependent Kinase Inhibitors: Useful Targets in Cell Cycle Regulation. Journal of Medicinal Chemistry, 43, 1-18.

85. Witherington, J., Bordas, V., Garland, S. L., Hickey, D. M., Ife, R. J., Liddle, J., ... \& Ward, R. W. (2003). 5-Aryl-pyrazolo [3, 4-b] pyridines: potent inhibitors of glycogen synthase kinase-3 (GSK-3). Bioorganic \& medicinal chemistry letters, 13(9), $1577-1580$.

86. Meijer, L., Flajolet, M., \& Greengard, P. (2004). Pharmacological inhibitors of glycogen synthase kinase 3. Trends in pharmacological sciences, 25(9), 471-480.

87. Brana, M. F., Cacho, M., García, M. L., Mayoral, E. P., López, B., de Pascual-Teresa, B., ... \& Lozach, O. (2005). Pyrazolo [3, 4 c] pyridazines as novel and selective inhibitors of cyclin-dependent kinases. Journal of medicinal chemistry, 48(22), 6843-6854.

88. Rakib, E.M., Abouricha, S., Hannioui, A., Benchat, N., Ait, M'barek, L., Zyad, A. (2006). Synthesis and in vitro Cytotoxicity Studies of Novel Triazolo[4,3-b]pyridazinones. Journal of the Iran Chemical Society, 3(3), 272-276.

89. Norbert, H., Eddy, S., (2002). 1,5-Dimethyl-6H-pyridazino[4,5-b]carbazole, a 3-Aza Bioisoster of the Antitumor Alkaloid Olivacine. Chemical \& Pharmaceutical Bulletin, 50(11), 1479-1483.

90. Malinka, W., Redzicka, A., Lozach, O. (2004). New derivatives of pyrrolo[3,4-d]pyridazinone and their anticancer effects. Farmaco, 59(6), 457-62.

91. Hübner, R. H., Gitter, W., Eddine El Mokhtari, N., Mathiak, M., Both, M., Bolte, H., ... \& Bewig, B. (2008). Standardized quantification of pulmonary fibrosis in histological samples. Biotechniques, 44(4), 507-517.

92. Greenwood, J. R., Vaccarella, G., Capper, H. R., Mewett, K. N., Allan, R. D., \& Johnston, G. A. (1996). Theoretical studies on the free-radical bromination of methyl-pyridazines in the synthesis of novel heterocyclic analogues of neurotransmitters. Journal of Molecular Structure: THEOCHEM, 368, 235-243.

93. Frick, N. T., \& Wright, P. A. (2002). Nitrogen metabolism and excretion in the mangrove killifish Rivulus marmoratus II. Significant ammonia volatilization in a teleost during air-exposure. Journal of experimental biology, 205(1), 91-100.

94. Möller, T., \& Trumbore, B. (2005). Fast, minimum storage ray/triangle intersection. In ACM SIGGRAPH 2005 Courses(p. 7). ACM.

95. Yan, H., Park, S. H., Finkelstein, G., Reif, J. H., \& LaBean, T. H. (2003). DNA-templated self-assembly of protein arrays and highly conductive nanowires. science, 301(5641), 1882-1884.

96. Griebel, G., Perrault, G., Tan, S., Schoemaker, H., Sanger, D.J. (1999). Comparison of the pharmacological properties of classical and novel BZ-omega receptor ligands. Behavior Pharmacology, 10(5):483-95.

97. Griebel, G., Perrault, G., Sanger, D.J., (1999). Differences in anxiolytic-like profile of two novel nonbenzodiazepine BZ (omega) receptor agonists on defensive behaviors of mice. Pharmacology \& Biochemical Behavior, 62(4), 689-94.

98. Fuks, B., Talaga, P., Huart, C., Henichart, J.P., Bertrand, K., Grimee, R., Lorent, G., (2005). In vitro properties of 5 (benzylsulfonyl)-4-bromo-2-methyl-3(2H)-pyridazinone: a novel permeability transition pore inhibitor. European Journal Pharmacology ,519(1-2):24-30.

99. Betti, L., Zanelli, M., Giannaccini, G., Manetti, F., Schenone, S., Strappaghetti, G. (2006). Synthesis of new piperazinepyridazinone derivatives and their binding affinity toward alpha1-, alpha 2-adrenergic and 5-HT1A serotoninergic receptors. Bioorganic \& Medicinal Chemistry, 14(8):2828-36.

100. Nagai, H., Suda, H., Iwama, T., Daikoku, M., Yanagihara, Y., Koda, A. (1992). Effect of NZ-107, a newly synthesized pyridazinone derivative, on antigen-induced contraction of human bronchial strips and histamine release from human lung fragments or leukocytes. International Archives Allergy Immunology, 98(1), 57-63.

101. Hibi, M., Shikada, K., Iwama, T., Yamamoto, A., Sakashita, M., Tanaka, S. (1989). Inhibitory effect of the newly synthesized pyridazinone derivative NZ-107 on bronchoconstriction induced by slow reacting substance of anaphylaxis in the guinea pig. Japanes Journal of Pharmacology, 51(3), 411-9.

102. Yamamoto A, Iwama T, Takeda H, Nagai H. (1995). Effects of NIP-502 on antigen-induced bronchial responses and allergic reactions in animal models. Jpn J Pharmacol, 68(1),47-55.

103. Huang, Q., Kong, Y., Liu, M., Feng, J., \& Liu, Y. (2008). Effect of oxadiazolyl 3 (2H)-pyridazinone on the larval growth and digestive physiology of the armyworm, Pseudaletia separata. Journal of insect science, 8(1), 19.

104. Abdelrazek, F.M., Michael, F.A., \& Mohamed, A.E. (2006). Synthesis and molluscicidal activity of some 1,3,4-triaryl-5chloropyrazole, pyrano[2,3-c]pyrazole, pyrazolylphthalazine and pyrano[2,3-d]thiazole derivatives. Arch Pharm, 339(6):305-12.

105. Yuefen, Z., Lian, S. L., Peter, S. D., Douglas, E. M., Chinh, V. T., Frank, R., ... \& Richard, E. S. (2008). Novel HCV NS5B polymerase inhibitors derived from 4-(10, 10-dioxo-10, 40-dihydro-10k6-benzo [10, 20, 40] thiadiazin-30-yl)-5-hydroxy-2Hpyridazin-3-ones. Part 2: Variation of the 2-and 6-pyridazinone substituents. Bioorg. \& Med. Chem. Lett, 18, 1419-1424.

106. Chai, B., Qian, X., Cao, S., Liu, H., \& Song, G. (2003). Synthesis and insecticidal activity of 1, 2, 4-triazole derivatives. Arkivoc, 2 , $141-145$

107. Károlyházy, L., Horváth, G., Mátyus, P. (2001). A novel pyridazino-fused ring system: synthesis of pyridazino[3,4-b]diazepam. Acta Pharmaceutica Hungarian, 71(2),168-70. 
108. Yalamanchili, P., Wexler, E., Hayes, M., Yu, M., Bozek. J., Kagan, M., Radeke, H.S., Azure, M., Purohit, A., Casebier, D.S. Robinson, S.P. (2007). Mechanism of uptake and retention of F-18 BMS-747158-02 in cardiomyocytes: a novel PET myocardial imaging agent. Journal Nuclear Cardiology, 14(6),782-8.

109. Fry, B. G., Roelants, K., Champagne, D. E., Scheib, H., Tyndall, J. D., King, G. F., .. \& Renjifo, C. (2009). The toxicogenomic multiverse: convergent recruitment of proteins into animal venoms. Annual review of genomics and human genetics, $10,483-511$.

110. Allerton, C.M., Andrews, M.D., Blagg, J., Ellis, D., Evrard, E., Green, M.P., Liu, K.K., McMurray, G., Ralph, M., Sanderson, V., Ward, R., Watson, L., (2009). Design and synthesis of pyridazinone-based 5-HT(2C) agonists. Bioorganic \& Medicinal Chemistry, 19(19), 5791-5.

111. Coudert, P., Duroux, E., Bastide P., Couquelet, J. (1991). Tronche P. Synthesis and evaluation of the aldose reductase inhibitory activity of new diaryl pyridazine-3-ones. Journal of Pharm Belgium, 46(6), 375-80.

112. Müller, R., Schmitt, S., Lingens, F. (1982). A novel non-heme iron-containing dioxygenase. Chloridazon-catechol dioxygenase from Phenylobacterium immobilis DSM 1986. European Journal of Biochemistry, 125(3), 579-84.

113. Pham, H.C., Lasserre, B., Pham, H.C.A., Palhares de, M.A.L., Tronche, P., Couquelet, J., Rubat C. (1988). A selective inhibitor of thromboxane synthetase activity of rabbit heart tissue: a pyridazinic derivative. Prostaglandins Leukot Essent Fatty Acids, $33(2), 143-7$. 